\title{
Staphylococcus aureus vs. Osteoblast: Relationship and Consequences in Osteomyelitis
}

\author{
Jérôme Josse, Frédéric Velard and Sophie C. Gangloff * \\ EA 4691 Biomatériaux et inflammation en site osseux, Pôle Santé, Université de Reims Champagne-Ardenne, Reims, France
}

Bone cells, namely osteoblasts and osteoclasts work in concert and are responsible for bone extracellular matrix formation and resorption. This homeostasis is, in part, altered during infections by Staphylococcus aureus through the induction of various responses from the osteoblasts. This includes the over-production of chemokines, cytokines and growth factors, thus suggesting a role for these cells in both innate and adaptive immunity. S. aureus decreases the activity and viability of osteoblasts, by induction of apoptosis-dependent and independent mechanisms. The tight relationship between osteoclasts and osteoblasts is also modulated by $S$. aureus infection. The present review provides a survey of the relevant literature discussing the important aspects of S. aureus and osteoblast interaction as well as the ability for antimicrobial peptides to kill intra-osteoblastic $S$. aureus, hence emphasizing the necessity for new anti-infectious therapeutics.

Keywords: Staphylococcus aureus, osteoblast, internalization, inflammation, antibiotics, antimicrobial peptide, phenol soluble modulin, small colony variants

\section{OPEN ACCESS}

Edited by:

Francois Vandenesch,

University of Lyon, France

Reviewed by:

Silvia T. Cardona,

University of Manitoba, Canada

Sophie Assant

Centre International de Recherche en

Infectiologie, France

*Correspondence:

Sophie C. Gangloff

sophie.gangloff@univ-reims.fr

Received: 17 September 2015 Accepted: 10 November 2015 Published: 26 November 2015

Citation: Josse J, Velard F and Gangloff SC (2015) Staphylococcus aureus vs.

Osteoblast: Relationship and Consequences in Osteomyelitis. Front. Cell. Infect. Microbiol. 5:85. doi: 10.3389/fcimb.2015.00085

\section{INTRODUCTION}

Bone is quantitatively the most abundant mineralized tissue in humans. It is composed of cells evolving in a tangle of collagen and non-collagenous proteins, which can be mineralized to form the bone extracellular matrix (BEM). Osteoblasts are the bone forming cells. First, osteoblasts synthesize an organic matrix around themselves and mineralize it to create the mature BEM (Ecarot-Charrier et al., 1983) where they are ultimately integrated as osteocytes (Dallas and Bonewald, 2010). The synthesis of the BEM is balanced by a resorption performed by osteoclasts. Rising from the fusion of monocytic precursors to form giant multinuclear cells, osteoclasts secrete $\mathrm{H}^{+}$protons and several proteases to resorb both inorganic and organic parts of the BEM (Edwards and Mundy, 2011). The concomitant bone formation and resorption create perpetual physiological homeostasis.

Osteoblast activity is altered in pathological conditions such as cancers, autoimmune diseases and infections. Osteomyelitis are damaging bone infections, that can lead to sequelae and if uncontrolled, to patients death. During childhood, osteomyelitis are mostly a result of

Abbreviations: S. aureus, Staphylococcus aureus; BEM, bone extracellular matrix; AMP, antimicrobial peptide; MSCRAMM, microbial surface components recognizing adhesive matrix molecule; PAMP, pathogen-associated molecular pattern; PRR, pattern recognition receptor; NOD, nucleotide-binding oligomerization domain; NLR, NOD like receptor; TLR, toll like receptor; TNFR-1, tumor necrosis factor receptor 1 ; TNF- $\alpha$, tumor necrosis factor $\alpha$; NF-кB, nuclear factor kappa B; MHC, major histocompatibility complex; RANK-L, receptor activator of NF-кB ligand; OPG, osteoprotegerin; TRAIL, tumor necrosis factor-related apoptosis-inducing ligand; DR, death receptor; PGE2, prostaglandin E2; HBD, human $\beta$-defensin; MBD, mouse $\beta$-defensin. 
hematogenous spread from distant infected tissues. In adults, surgical procedures are becoming increasingly responsible for a direct contamination of bone tissue, especially in presence of medical devices (Montanaro et al., 2011). The incidence of osteomyelitis varies from 1 to $55 \%$ in open fracture cases as a function of the grade of the fracture (Kim and Leopold, 2012; Hogan et al., 2013). Germ concentration, pathogenicity of the implicated pathogen or systemic factors such as nicotine, obesity or diabetes mellitus can also favor the prognosis of direct osteomyelitis (Hogan et al., 2013). Osteomyelitis are typically of bacterial origin, notably Staphylococcus species, where Staphylococcus aureus is the most prevalent pathogen (Lew and Waldvogel, 2004), also responsible for various community or hospital-acquired infections like skin abscess, pneumonia or septic arthritis (Lowy, 1998).

Infection of osteoblasts by $S$. aureus is a keystone, a determining element in the development of osteomyelitis in bone tissue and as such this review focuses on the interaction between $S$. aureus and the osteoblasts that play an important role in bone homeostasis. S. aureus directly interacts with osteoblasts both in the extracellular and intracellular space following its internalization (Hudson et al., 1995). Each interaction specifically leads to the induction of various and distinct responses from the osteoblasts.

S. aureus possesses on its surface an arsenal of pathogenassociated molecular patterns (PAMP) that interact with osteoblasts to induce the production of chemokines and cytokines that then recruit and activate innate and adaptive immune cells (Heilmann, 2011; Claro et al., 2013). In addition to inflammatory response, $S$. aureus can also induce the death of osteoblasts and increase osteoclastogenesis through osteoblasts stimulation thus resulting in an imbalanced bone homeostasis (Tucker et al., 2000; Widaa et al., 2012). The combination of these effects leads to inflammatory bone loss.

Recent studies have consequently focused on antibiotics and their ability to kill intracellular $S$. aureus as well as on antimicrobial peptides (AMP) that can be produced by osteoblasts (Varoga et al., 2009; Zhu et al., 2014) or chemically synthetized (Choe et al., 2015).

S. aureus embodies a major clinical challenge, as chronic osteomyelitis with $S$. aureus are difficult to treat with antibiotics (Spellberg and Lipsky, 2012). The ability of S. aureus to survive in osteoblasts after internalization can protect it from immune cells but also from the antibiotics that may not penetrate the cells (Valour et al., 2015a).

We hereby provide an overview of the relationship and interaction between $S$. aureus and osteoblasts, from the onset of the infection to new therapeutics.

\section{BONE EXTRACELLULAR MATRIX, A NICHE FOR S. AUREUS}

The capacity of $S$. aureus to infect bone-and more specifically the osteoblast-is tightly correlated to its ability to bind the BEM components, notably via multiple adhesins called the MSCRAMMs which stands for microbial surface components recognizing adhesive matrix molecules (Heilmann, 2011). The proteins and glycans present in the BEM are all potential S. aureus binding sites. The most studied of these are type I collagen, bone sialoprotein, osteopontin, and fibronectin because they directly interact with S. aureus (Figure 1).

Type I collagen represents approximately $90-95 \%$ of the organic fraction of the BEM, thus supporting a major role for the collagen adhesin (Cna) of $S$. aureus in the pathogenesis of osteomyelitis. Cna has resulted in being pivotal for settling osteomyelitis through hematogenous spread in a murine model (Elasri et al., 2002). Cna is highly expressed during the stage of exponential growth of S. aureus (Gillaspy et al., 1997) and Cnapositive strains are often associated with a slime formation, a state that enhances the pathogenicity of $S$. aureus in implantassociated osteomyelitis (Montanaro et al., 1999).

The bone sialoprotein represents however another means for $S$. aureus to bind the BEM. This protein constitutes approximately $8 \%$ of all non-collagenous proteins found in bone (Fisher et al., 1990). The bone sialoprotein binding protein (bbp) is a member of the staphylococcal serine-aspartate dipeptide repeat (sdr) family (Tung et al., 2000) and is one of the first adhesins studied for its potential role in osteomyelitis caused by S. aureus (Rydén et al., 1989). Bbp could be considered as an adhesin with several ligands due to the recognition of fibrinogen in a non-osseous context (Vazquez et al., 2011). The presence of both cna and bbp genes in $S$. aureus is considered as a major marker of virulence in isolates from implant-associated osteomyelitis (Campoccia et al., 2009).

An involvement of $S$. aureus Map-a functional bacterial analog to mammalian MHC class II molecules-in osteomyelitis is also speculated in regard to its ability to bind recombinant osteopontin (Jönsson et al., 1995). The ability of S. aureus to bind to biological osteopontin has nevertheless not been reported yet.

Fibronectin is the most studied component of the extracellular matrix in staphylococcal infection, especially in osteomyelitis. Fibronectin acts as a bridge between $S$. aureus and the osteoblasts. On the one hand, $S$. aureus holds two types of proteins that can bind to fibronectin on its surface: the fibronectin binding proteins $\mathrm{A}$ and $\mathrm{B}$ (FnBP A/B). On the other hand, fibronectin connects to the osteoblasts through the $\alpha 5 \beta 1$ integrin. This "fibronectin bridge" allows the attachment of $S$. aureus and also favors its internalization by non-phagocytic cells like many cell types (Dziewanowska et al., 1999; Peacock et al., 1999; Ahmed et al., 2001; Kintarak et al., 2004).

BEM attachment represents a major step in osteomyelitis onset as $10-60 \%$ of studied $S$. aureus clones express $c n a, b b p$, and $f n b B$ genes and $100 \%$ express $f n b A$ or clumping factor $A$ and $B$ genes (Otsuka et al., 2006; Campoccia et al., 2009; Atshan et al., 2012; Post et al., 2014). In specific osteomyelitis case, cna and $b b p$ genes were more frequently identified in non-implant related infections than in implant-related infections (Post et al., 2014). Of note, expression of cna gene is increased in methicillin resistant clones compared with methicillin sensible ones (Atshan et al., 2012). To illustrate this point, the combination of $c n a$ and $b b p$ genes characterizes ST30-a pandemic community-acquired methicillin resistant $S$. aureus that causes osteomyelitis-(Otsuka et al., 2006; Dhanoa et al., 2012). 


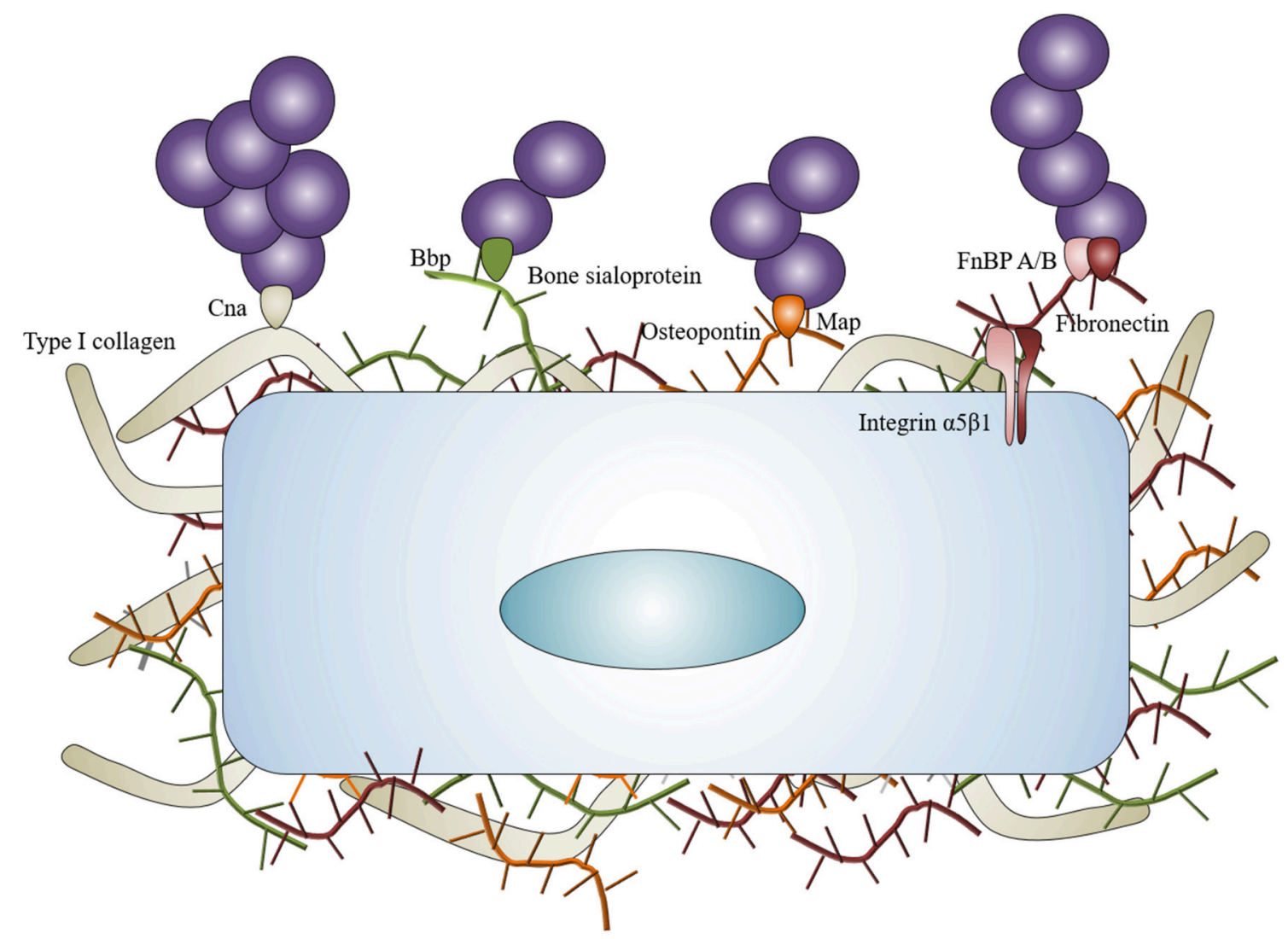

FIGURE 1 | Staphylococcus aureus interaction with BEM. Staphylococcus aureus can interact with the BEM to concentrate around osteoblasts. Collagen adhesin (Cna) links with type I collagen, bone sialoprotein binding protein (Bbp) links with bone sialoprotein, MHC II analog protein (Map) can potentially link osteopontin. Fibronectin binding proteins A and B (FnBP A/B) link with fibronectin and act as bridges between Staphylococcus aureus and osteoblasts through $\alpha 5 \beta 1$ integrin.

BEM is therefore an important actor in the first step of $S$. aureus infection as it is produced by and connected to osteoblasts. It allows the bacteria to bind and concentrate around osteoblasts, particularly for staphylococcal clones possessing $c n a, b b p$, and/or $f n b B$ genes.

\section{INVASION/INTERNALIZATION OF S. AUREUS INTO OSTEOBLASTS}

Ogawa et al. were the first to report the capacity of endothelial cells to "engulf" S. aureus (Ogawa et al., 1985). It has been shown since this observation that $S$. aureus can adhere to and invade cultured osteoblasts (Table 1), as well as osteoblasts and osteocytes in vivo (Hudson et al., 1995; Reilly et al., 2000; Bosse et al., 2005).

The ability of fibronectin to link with $\alpha 5 \beta 1$ integrin has currently been considered as the most common pathway for the internalization of $S$. aureus in endothelial cells and osteoblasts (Figure 2). Though this mechanism is specific to $S$. aureus (Khalil et al., 2007), deleting FnBP A/B in S. aureus does not completely abrogate its internalization by osteoblasts, suggesting the involvement of other mechanisms in this process (Ahmed et al., 2001). Cna and Bbp actually favor the FnBP-mediated internalization (Testoni et al., 2011) whereas other MSCRAMMs of $S$. aureus are involved in integrin-mediated internalization (Hirschhausen et al., 2010; Zapotoczna et al., 2013). Other BEM components like collagen or bone sialoprotein, also bind to multiple integrins supporting the possibility of still unknown "MSCRAMM/BEM component/integrin" bridge systems to initiate the internalization of $S$. aureus by osteoblasts (Grzesik and Robey, 1994).

Independently of the extracellular events, the involvement of the cytoskeletal elements, particularly actin microfilaments, has been shown during the internalization of $S$. aureus (Ellington et al., 1999; Jevon et al., 1999; Figure 2). In addition, the internalization process of $S$. aureus can occur with dead bacteria but not dead osteoblasts. This suggests that the internalization process is more an active cellular mechanism rather than an active bacterial mechanism (Hudson et al., 1995).

Internalization of $S$. aureus by osteoblasts is a key element in the spreading of the infection. It allows $S$. aureus to persist inside osteoblasts - protected from the immune system-and it gives to S. aureus the opportunity to sustain the infection. 
TABLE 1 | Staphylococcus aureus internalization by cultured osteoblasts.

\begin{tabular}{|c|c|c|c|c|}
\hline Cells & Strains & MOI & Observations & Author/Year \\
\hline CECOs & $\mathrm{Lab}$ & - & $\begin{array}{l}\text { Adherence, internalization and intracellular survival of Staphylococcus aureus } \\
\text { inside osteoblasts }\end{array}$ & $\begin{array}{l}\text { Hudson et al., } \\
1995\end{array}$ \\
\hline MC3T3-E1 & UAMS-1 & - & $\begin{array}{l}\text { Involvement of actin microfilaments, microtubules and clathrincoated pits in the } \\
\text { internalization of Staphylococcus aureus by osteoblasts }\end{array}$ & $\begin{array}{l}\text { Ellington et al., } \\
1999\end{array}$ \\
\hline MG-63, NHOs & Lab, Clinic & $30: 1$ & $\begin{array}{l}\text { Role of cytoskeleton of osteoblasts, notably actin microfilaments, in } \\
\text { internalization of Staphylococcus aureus }\end{array}$ & Jevon et al., 1999 \\
\hline MG-63 & $\mathrm{Lab}$ & $300: 1$ & $\begin{array}{l}\text { Role of fibronectin binding proteins } \mathrm{A} / \mathrm{B}(\mathrm{FnBP} \mathrm{A} / \mathrm{B}) \text { in the internalization of } \\
\text { Staphylococcus aureus in osteoblasts }\end{array}$ & Ahmed et al., 2001 \\
\hline $\mathrm{NHOS}$ & UAMS-1 & $\begin{array}{l}25: 1 \\
75: 1 \\
250: 1\end{array}$ & $\begin{array}{l}\text { Release of intracellular Staphylococcus aureus by dead osteoblasts and ability to } \\
\text { re-infect new osteoblasts }\end{array}$ & $\begin{array}{l}\text { Ellington et al., } \\
2003\end{array}$ \\
\hline MG-63 & $\mathrm{Lab}$ & $300: 1$ & $\begin{array}{l}\text { Correlation between SigB expression in Staphylococcus aureus and its capacity } \\
\text { for internalization inside osteoblasts }\end{array}$ & Nair et al., 2003 \\
\hline MG-63 & $\mathrm{Lab}$ & $\begin{array}{l}50: 1 \\
200: 1 \\
500: 1\end{array}$ & $\begin{array}{l}\text { Internalization of Staphylococcus aureus into osteoblasts through a fibronectin } \\
\text { bridge to integrin } \alpha 5 \beta 1\end{array}$ & Khalil et al., 2007 \\
\hline MG-63 & Clinic & - & $\begin{array}{l}\text { Synergistic role of Cna and Bbp adhesins in the initial adhesion of } \\
\text { Staphylococcus aureus to osteoblasts, favoring the subsequent } \\
\text { FnBPA-mediated internalization. }\end{array}$ & Testoni et al., 2011 \\
\hline $\mathrm{pHOB}$ & Lab, Clinic & $50: 1$ & $\begin{array}{l}\text { Staphylococcus aureus can persist within osteoblasts for several weeks. } \\
\text { Persistence induces bacterial phenotypic diversity, including SCV phenotypes, } \\
\text { accompanied by changes in virulence factor expression }\end{array}$ & $\begin{array}{l}\text { Tuchscherr et al., } \\
2011\end{array}$ \\
\hline MG-63 & $\mathrm{Lab}$ & $10: 1$ & $\begin{array}{l}\text { Evidence of a trafficking of intracellular Staphylococcus aureus into the late } \\
\text { endosomal/lysosomal compartment in osteoblasts }\end{array}$ & $\begin{array}{l}\text { Jauregui et al., } \\
2013\end{array}$ \\
\hline UMR-106 & $\mathrm{Lab}$ & $\begin{array}{l}100: 1 \\
500: 1 \\
1000: 1\end{array}$ & $\begin{array}{l}\text { Internalization and survival of Staphylococcus aureus within osteoblasts and } \\
\text { macrophages led to differential responses }\end{array}$ & $\begin{array}{l}\text { Hamza and Li, } \\
2014\end{array}$ \\
\hline $\mathrm{pHOB}$ & Lab, Clinic & $50: 1$ & $\begin{array}{l}\text { Chronic osteomyelitis isolates were characterized by a high host cell invasion } \\
\text { rate, low cytotoxicity and the ability to persist and adapt within osteoblasts } \\
\text { through SCVs formation }\end{array}$ & Kalinka et al., 2014 \\
\hline $\mathrm{pHOB}$ & Lab, Clinic & $50: 1$ & $\begin{array}{l}\text { Sigma Factor SigB is an essential factor that enables Staphylococcus aureus to } \\
\text { switch from the highly aggressive phenotype that settles an acute infection to a } \\
\text { silent SCV-phenotype that allows for long-term intracellular persistence }\end{array}$ & $\begin{array}{l}\text { Tuchscherr et al., } \\
2015\end{array}$ \\
\hline $\mathrm{pHOB}$ & Lab, Clinic & $50: 1$ & $\begin{array}{l}\text { Staphylococcus aureus continuously upregulated the expression of SigB during } \\
\text { intracellular persistence. The increased SigB expression was accompanied by } \\
\text { upregulation of adhesins and downregulation of toxins, which are characteristic } \\
\text { for SCVs }\end{array}$ & $\begin{array}{l}\text { Tuchscherr and } \\
\text { Löffler, } 2015\end{array}$ \\
\hline MG-63 & Clinic & $100: 1$ & $\begin{array}{l}\text { Lack of delta-toxin production was significantly associated with osteomyelitis } \\
\text { chronicity, osteoblast invasion and biofilm formation }\end{array}$ & $\begin{array}{l}\text { Valour et al., } \\
2015 b\end{array}$ \\
\hline
\end{tabular}

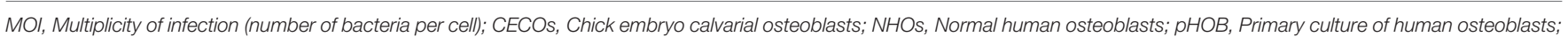

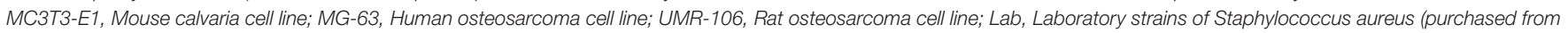

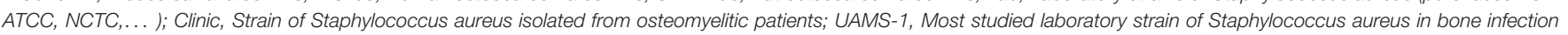
model.

\section{INTRACELLULAR S. AUREUS AND PERSISTENCE INTO OSTEOBLASTS}

S. aureus can be localized in vesicles once inside the osteoblasts (Figure 2). A co-localization of fluorescent intracellular S. aureus and a lysosomal-associated membrane marker highlighted the trafficking of live bacteria into the late endosomal/lysosomal vesicles in osteoblasts. This hints to suggest that $S$. aureus survives inside the vesicles (Jauregui et al., 2013). Moreover, a recent study shows that internalization of $S$. aureus is higher in macrophages-a typical professional phagocytic cells-than in osteoblasts whereas the percentage of intracellularly surviving $S$. aureus was higher in osteoblasts than in macrophages (Hamza and Li, 2014). As non-professional phagocytic cells, the lack of an effective intracellular bacterial clearance program in osteoblasts may allow $S$. aureus to survive longer inside the latter. The ability to survive inside osteoblasts is nevertheless explained by the exit of $S$. aureus from the vesicles and its release in the cytoplasm to escape proteolytic activity of the lysosome.

There are several types of membrane-damaging factors such as hemolysins, bi-component leukocidins and phenol soluble modulins (PSM) among S. aureus arsenal of virulence factors (reviewed by Vandenesch et al., 2012). These factors are involved in the escape of $S$. aureus from intracellular vesicles.

PSM $\alpha$ - a member of the PSM family - has been observed to favor the escape of $S$. aureus from vesicles to the cytoplasm in 


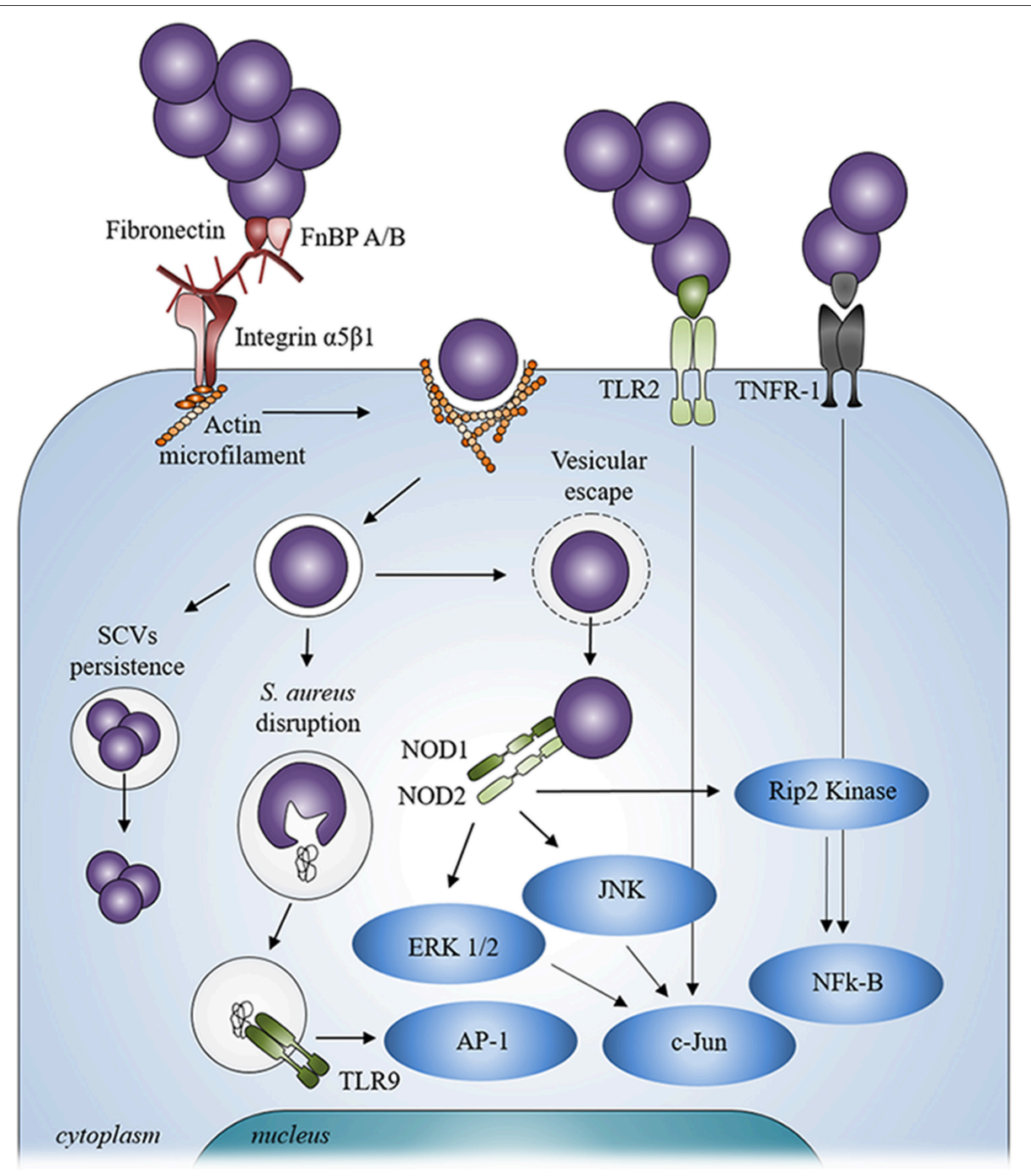

FIGURE 2 | Staphylococcus aureus signaling mechanism after contact and internalization by osteoblasts. After internalization, Staphylococcus aureus can escape from vesicle, be disrupted from inside the vesicle or persist inside osteoblasts through a SCV phenotype. Staphylococcus aureus can also interact with extracellular receptors TLR2 and TNFR-1 and with intracellular receptors TLR9 and NODs after its internalization into osteoblasts thanks to $\alpha 5 \beta 1$ integrin and actin filaments.

different types of cell line (Grosz et al., 2014). In Hela cells, a similar mechanism of vesicular escaping has been also identified for either PSM $\beta$ or $\delta$-toxin. These two members of the PSM family make the escape possible from the vesicles in synergy with $\beta$-toxin (Giese et al., 2011).

$\operatorname{PSM} \alpha$ has been shown to mediate the cytotoxicity for intracellular S. aureus in osteoblast/S. aureus specific interaction (Cassat et al., 2013; Rasigade et al., 2013). Valour et al. more recently demonstrated that lack of $\delta$-toxin in clinical isolates from $S$. aureus bone and joint infections was correlated with the chronicity of the infection (Valour et al., 2015b).

A tight relationship exists between vesicular escape, cytoxicity, and membrane-damaging virulence factors. We can easily assume that PSMs allow the escape from the vesicle and then acts on the cell membrane so as jeopardize osteoblasts. This phenomenon needs some investigations with regards to the $S$. aureus/osteoblast interaction.

In addition to the vesicular escape, intracellular persistence of $S$. aureus inside osteoblasts is also supported by the presence of small colony variants (SCV). SCVs are a slow-growing subpopulation of bacteria with atypical colony morphology on agar plates and unusual biochemical characteristics. SCVs consist of higher capacities for intracellular persistence and are less liable to antibiotics than their wild-type counterparts (Proctor et al., 2006). Involvement of SCVs in intracellular persistence might be due to a better susceptibility to host uptake and/or a selection of SCVs due to intracellular environment properties (Proctor et al., 2014). SCVs were observed in in vitro models of osteoblast/S. aureus interaction (Valour et al., 2015a,b). A high percentage of SCVs was correlated with less cytoxicity of 
osteoblasts in isolates from chronic osteomyelitis with $S$. aureus (Kalinka et al., 2014). In this context, Sigma Factor SigB of $S$. aureus was shown to be an essential factor that leads to $S$. aureus to switch from the highly aggressive phenotype that settles an acute infection to a silent SCV-phenotype that leads to a long-term intracellular persistence (Tuchscherr et al., 2015). A continuous upregulation of SigB expression during intracellular persistence was correlated with the upregulation of adhesins and downregulation of toxins, which are characteristic for SCVs (Tuchscherr and Löffler, 2015). The impact of SigB in S. aureus internalization by osteoblasts was already observed more than a decade ago (Nair et al., 2003). Moreover, SCVs were observed to rapidly revert to the fully virulent wild-type form when leaving the intracellular location and infecting new cells (Tuchscherr et al., 2011).

Membrane-damaging virulence factors and SCVs are major parameters in intracellular persistence of $S$. aureus inside osteoblasts. On the one hand, PSMs make the escape from the intracellular vesicle to the cytoplasm easier but also increase the osteoblast death. On the other hand, SCVs can easily persist inside osteoblasts thanks to their lowered virulence factors.

\section{RECEPTORS INVOLVED IN THE INTERACTION BETWEEN S. AUREUS AND OSTEOBLASTS}

In addition to binding to the BEM, S. aureus can also directly stimulate osteoblasts, mostly through its PAMPs, leading to various cellular responses (summarized in Table 2). The PAMPs can interact with the osteoblasts pattern recognition receptors (PRR) such as Toll-like receptors (TLR) and nucleotide-binding oligomerization domains (NOD) like receptors (NLR), as well as with the tumor necrosis factor receptor 1 (TNFR-1; Figure 2).

TLR is a family of thirteen membrane-bound PRRs that can interact with different bacterial components (Kawai and Akira, 2010). TLR-2, TLR-4, TLR-5, and TLR-9 have been observed in osteoblasts. TLR-2 is an extracellular receptor that can recognize the PAMPs from S. aureus (Fournier, 2012). It induces the release of AMPs as well as the induction of osteoblast apoptosis following its activation by S. aureus (Varoga et al., 2009; Chen et al., 2014). TLR- 4 and TLR-5 take part in responses toward Gram negative bacteria, by respectively recognizing LPS and flagellin but are not involved in S. aureus/osteoblast interaction (Kikuchi et al., 2001; Madrazo et al., 2003).

As opposed to TLRs $-2,-4$, and -5 , TLR-9 is an intracellular member of the TLR family. It is bound to the membrane of intracellular vesicle. TLR-9 recognizes the CpG oligodesoxynucleotides of bacterial DNA and is able to detect the presence of S. aureus DNA (Zou et al., 2003). This can however occur but after the disruption or disintegration of $S$. aureus within the intracellular vesicles, leading to the release of its DNA that then binds to TLR-9 and induces the activation of signaling cascades (Wolf et al., 2011; Figure 2).

As above mentioned, intracellular $S$. aureus can also escape from a vesicle and be released into the cytosol of osteoblasts following its internalization. $S$. aureus can induce in this case a response through the NLRs, a family of 22 intracellular PRRs (Figure 2), NOD1, NOD2, NLRP3, and NLRC4 have been studied in osteoblasts among the latter family. Over-expression of NOD1 and NOD2 was assessed in osteoblasts infected by intracellular $S$. aureus and led intracellular signaling to be activated and to the production of immune molecules (Marriott et al., 2005). Another study focusing on NOD2 backs the idea that this NLR may serve differential roles in osteoblasts, promoting inflammatory responses to invasive bacteria while tempering cell responses to extracellular and/or passively internalized bacterial species, such as S. aureus (Chauhan and Marriott, 2010). Two other NLRs, NLRP3, and NLRC4, were also evidenced in osteoblasts. NLRP3 is expressed in osteoblasts whereas NLRC4 expression was not found. The role of NLRP3 in bacteria-related osteoblast death was studied for the invasive bacteria Salmonella enterica but not for S. aureus (McCall et al., 2008).

It has been recently reported that $S$. aureus can also interact through the extracellular TNFR-1 on epithelial cells and osteoblasts independently from PRRs such as TLRs and NLRs (Gómez et al., 2004; Claro et al., 2013). Originally described as an exclusive receptor for the Tumor Necrosis Factor $\alpha$ (TNF$\alpha$ ), it was shown that TNFR-1 interacts with the protein A of $S$. aureus and may cause the release of cytokines, the apoptosis of osteoblasts, or an unbalanced bone homeostasis (Claro et al., 2011, 2013; Widaa et al., 2012).

It was proved that many signaling pathways are activated in S. aureus-infected osteoblasts including ERK 1/2, JNK, cJun, AP-1, Rip2 Kinase and NF- $\kappa$ B following the interaction with PRRs or TNFR-1, (Ellington et al., 2001; Wright and Friedland, 2002; Marriott et al., 2005; Ning et al., 2010; Claro et al., 2013; Figure 2). S. aureus can virtually activate different signaling pathways through either extracellular or intracellular receptors. This combination of signaling mechanisms highlights the diversity and the complexity of the osteoblast response to various signals and/or bacterial infections.

\section{IMPLICATION OF THE $S$. AUREUS-CHALLENGED OSTEOBLASTS IN THE IMMUNE RESPONSE}

Following contact/internalization of $S$. aureus, the first line of defense of the osteoblasts is to secrete inflammatory factors like cytokines, chemokines and growth factors, all of which are able to activate and recruit immune cells from the innate or adaptive immune systems (Turner et al., 2014; Figure 3).

More specifically, the osteoblast production of IL-6, CCL2 (MCP-1), CCL3 (MIP-1 $\alpha$ ), and CCL5 (RANTES) increases following $S$. aureus infection. These mediators are able to recruit and activate macrophages (Bost et al., 1999, 2001; Ning et al., 2011; Dapunt et al., 2014). An over-production of G-CSF and GM-CSF-two growth factors that favor the maturation of leukocytes-has also been demonstrated (Bost et al., 2000). CXCL8 (IL-8) and CXCL2 (MIP-2 $\alpha$ also called GRO- $\beta$ ) - two neutrophil chemoattractants - are also up-regulated during osteoblasts/S. aureus interaction (Wright and Friedland, 2002, 2004; Dapunt et al., 2014). Through releasing these mediators, 
TABLE 2 | In vitro consequences of Staphylococcus aureus/osteoblast interaction.

\begin{tabular}{|c|c|c|c|c|}
\hline Cells & Strains & MOI & Observations & Author/Year \\
\hline MNCOs, NHOs & UAMS-1 & $\begin{array}{l}25: 1,75: 1 \\
250: 1\end{array}$ & $\begin{array}{l}\text { Upregulation of expression and release of IL-6 and IL-12 in infected } \\
\text { osteoblasts }\end{array}$ & Bost et al., 1999 \\
\hline MNCOs, NHOS & UAMS-1 & $\begin{array}{l}25: 1,75: 1 \\
250: 1\end{array}$ & $\begin{array}{l}\text { Upregulation of expression and release of GM-CSF and G-CSF in } \\
\text { infected osteoblasts }\end{array}$ & Bost et al., 2000 \\
\hline MC3T3-E1 & UAMS-1 & 250:1 & Intracellular Staphylococcus aureus induces apoptosis of osteoblasts & Tucker et al., 2000 \\
\hline MNCOs, NHOs & UAMS-1 & $\begin{array}{l}25: 1,75: 1 \\
250: 1\end{array}$ & Induction of expression and release of TRAIL in infected osteoblasts & $\begin{array}{l}\text { Alexander et al., } \\
2001\end{array}$ \\
\hline MNCOs, NHOs & UAMS-1 & $\begin{array}{l}25: 1,75: 1 \\
250: 1\end{array}$ & $\begin{array}{l}\text { Upregulation of expression and release of MCP-1 in infected } \\
\text { osteoblasts, but not IL-3 }\end{array}$ & Bost et al., 2001 \\
\hline MNCOs, NHOs & UAMS-1, & $\begin{array}{l}25: 1,75: 1 \\
250: 1\end{array}$ & $\begin{array}{l}\text { Increase of phosphorylation of ERK } 1 \text { and } 2 \text { and activation of c-jun in } \\
\text { Staphylococcus aureus-infected osteoblasts }\end{array}$ & Ellington et al., 2001 \\
\hline MG-63, NHOs & Clinic & $10: 1,1: 1$ & $\begin{array}{l}\text { Upregulation of expression and release of IL-8, IP-10, RANTES, MCP-1 } \\
\text { in infected osteoblasts }\end{array}$ & $\begin{array}{l}\text { Wright and } \\
\text { Friedland, } 2002\end{array}$ \\
\hline MNCOs, NHOs & UAMS-1 & $\begin{array}{l}75: 1 \\
250: 1\end{array}$ & Upregulation of expression and release of IP-10 in infected osteoblasts & Gasper et al., 2002 \\
\hline MNCOs, NHOs & UAMS-1 & $\begin{array}{l}25: 1,75: 1 \\
250: 1\end{array}$ & $\begin{array}{l}\text { Upregulation of expression of IL-1 } \beta \text { and IL-18 in infected osteoblasts, } \\
\text { but no release of the related proteins in spite of the presence of } \\
\text { caspase I }\end{array}$ & Marriott et al., 2002 \\
\hline MNCOs, NHOs & UAMS-1 & $\begin{array}{l}25: 1,75: 1 \\
250: 1\end{array}$ & $\begin{array}{l}\text { Expression of TRAIL in infected osteoblasts induces apoptosis and } \\
\text { activation of caspase-8 }\end{array}$ & $\begin{array}{l}\text { Alexander et al., } \\
2003\end{array}$ \\
\hline MNCOs, NHOs & UAMS-1 & $\begin{array}{l}25: 1,75: 1 \\
250: 1\end{array}$ & $\begin{array}{l}\text { Upregulation of expression and production of CD40 in infected } \\
\text { osteoblasts and mediation of cytokine induction }\end{array}$ & $\begin{array}{l}\text { Schrum et al., } \\
\text { 2003b }\end{array}$ \\
\hline MNCOs, NHOs & UAMS-1 & $\begin{array}{l}25: 1,75: 1 \\
250: 1\end{array}$ & $\begin{array}{l}\text { Upregulation of mRNA and surface expression of MHC II in infected } \\
\text { osteoblasts }\end{array}$ & Schrum et al., 2003a \\
\hline MNCOs & Bacterial DNA & - & $\begin{array}{l}\text { Induction of osteoclastogenesis by ligation of bacterial DNA upon } \\
\text { TLR-9 in osteoblasts }\end{array}$ & Zou et al., 2003 \\
\hline MG-63, NHOs & Clinic & $10: 1,1: 1$ & $\begin{array}{l}\text { Effect of Th2 cytokines, PGE2 and dexamethasone on release and } \\
\text { expression of RANTES, MCP-1, IP-10, IL-8 from infected osteoblasts }\end{array}$ & $\begin{array}{l}\text { Wright and } \\
\text { Friedland, } 2004\end{array}$ \\
\hline MNCOs & UAMS-1 & $\begin{array}{l}25: 1,75: 1 \\
250: 1\end{array}$ & $\begin{array}{l}\text { Stimulation of Nod1 and Nod2 by intracellular Staphylococcus aureus } \\
\text { and related cytokine release }\end{array}$ & Marriott et al., 2005 \\
\hline MNCOs, NHOs & UAMS-1 & $125: 1$ & $\begin{array}{l}\text { Decrease of sensibility to antibiotics for intracellular established } \\
\text { Staphylococcus aureus }\end{array}$ & Ellington et al., 2006 \\
\hline MNCOs, NHOs & UAMS-1, Lab & $25: 1,75: 1$ & $\begin{array}{l}\text { Expression of TRAlL is observed in both infected and uninfected } \\
\text { osteoblasts in infected cultures }\end{array}$ & Reott et al., 2008 \\
\hline MNCOs, & UAMS-1, Clinic & $\begin{array}{l}25: 1,75: 1 \\
250: 1\end{array}$ & $\begin{array}{l}\text { Upregulation of expression and production of RANK-L and production } \\
\text { of PGE2 via COX-2 activation in infected osteoblasts }\end{array}$ & Somayaji et al., 2008 \\
\hline hFOBs & - & Supernatant & $\begin{array}{l}\text { Up-regulation of the production of HBD-2 by osteoblasts challenged } \\
\text { with Staphylococcus aureus supernatants }\end{array}$ & Varoga et al., 2008 \\
\hline SaoS-2, NHOs & - & Supernatant & $\begin{array}{l}\text { Production of HBD- } 3 \text { by osteoblasts via TLR2 after stimulation with } \\
\text { Staphylococcus aureus supernantant }\end{array}$ & Varoga et al., 2009 \\
\hline MNCOs & UAMS-1 & $\begin{array}{l}25: 1,75: 1 \\
250: 1\end{array}$ & $\begin{array}{l}\text { Modulation of osteoblast response to Staphylococcus aureus through } \\
\text { NOD2 }\end{array}$ & $\begin{array}{l}\text { Chauhan and } \\
\text { Marriott, } 2010\end{array}$ \\
\hline SV40 hOBs & UAMS-1 & $250: 1$ & $\begin{array}{l}\text { Release of MCP-1 and IL-6 in infected osteoblasts through NF-kB } \\
\text { regulation }\end{array}$ & Ning et al., 2010 \\
\hline SV40 hOBs & UAMS-1 & $250: 1$ & $\begin{array}{l}\text { Necessity of attachment of Staphylococcus aureus to osteoblasts but } \\
\text { not internalization for activation of NF-kB }\end{array}$ & Ning et al., 2010 \\
\hline MNCOs, NHOs & UAMS-1, Lab & $\begin{array}{l}25: 1,75: 1 \\
250: 1\end{array}$ & $\begin{array}{l}\text { Expression of TRAIL death receptors, DR4 and DR5, and decrease of } \\
\text { OPG production in infected osteoblasts }\end{array}$ & Young et al., 2011 \\
\hline MC3T3-E1 & Lab & - & $\begin{array}{l}\text { Induction of osteoblast apoptosis via Caspase-3 and expression of } \\
\text { RANK-L thanks to the binding of SpA from Staphylococcus aureus to } \\
\text { TNFR-1 of osteoblasts }\end{array}$ & Claro et al., 2011 \\
\hline МС3Т3-E1 & Lab & - & $\begin{array}{l}\text { Inhibition of the osteoblast proliferation, induction of the migration of } \\
\text { pre-osteoclasts and osteoclastogenesis through SpA from } \\
\text { Staphylococcus aureus }\end{array}$ & Widaa et al., 2012 \\
\hline МС3Т3-E1, SaoS-2 & Clinic & Supernatant & $\begin{array}{l}\text { Dose-dependent cytotoxicity of PSM } \alpha \text { of Staphylococcus aureus on } \\
\text { osteoblasts }\end{array}$ & Cassat et al., 2013 \\
\hline
\end{tabular}


TABLE 2 | Continued

\begin{tabular}{|c|c|c|c|c|}
\hline Cells & Strains & MOI & Observations & Author/Year \\
\hline МС3Т3-E1 & $\mathrm{Lab}$ & - & SpA binds to TNFR- 1 which activates NF-kB and the release of IL-6 & Claro et al., 2013 \\
\hline MC3T3-E1 & $\mathrm{Lab}$ & $100: 1$ & $\begin{array}{l}\text { PVL, SpA and Coa of Staphylococcus aureus induce apotosis and } \\
\text { upregulate RANK-L expression in osteoblasts }\end{array}$ & Jin et al., 2013 \\
\hline MG-63 & Lab, clinic & $100: 1$ & $\begin{array}{l}\text { Killing effect of PSM } \alpha \text { secreted by intracellular Staphylococcus aureus } \\
\text { on osteoblasts }\end{array}$ & $\begin{array}{l}\text { Rasigade et al., } \\
2013\end{array}$ \\
\hline MC3Т3-E1 & $\mathrm{Lab}$ & Supernatant & $\begin{array}{l}\text { Induction of production of MDB-14 (a murine ortholog HDB-3) by } \\
\text { Staphylococcus aureus-infected osteoblasts through MAPK and } \\
\text { NF-kB pathways }\end{array}$ & Zhu et al., 2013 \\
\hline $\mathrm{NHOS}$ & UAMS-1, clinic & $\begin{array}{l}\text { Biofilm } \\
\text { supernatant }\end{array}$ & $\begin{array}{l}\text { Decrease of osteoblast viability, inhibition of osteogenic differentiation } \\
\text { and increase of RANKL expression by osteoblasts by biofilm } \\
\text { components of Staphylococcus aureus }\end{array}$ & Sanchez et al., 2013 \\
\hline MC3T3-E1 & $\mathrm{Lab}$ & $100: 1$ & $\begin{array}{l}\text { Apoptosis and decrease of osteogenic differentiation in response to } \\
\text { Staphylococcus aureus through TLR2 expression and JNK activation }\end{array}$ & Chen et al., 2014 \\
\hline Primary osteoblasts & $\mathrm{Lab}$ & $\begin{array}{l}20: 1 \\
100: 1 \\
500: 1\end{array}$ & $\begin{array}{l}\text { Production of CCL2 and CXCL3 by osteoblasts following stimulation by } \\
\text { Staphylococcus aureus }\end{array}$ & Dapunt et al., 2014 \\
\hline MC3T3-E1 & $\mathrm{Lab}$ & $100: 1$ & $\begin{array}{l}\text { Expression of miR-24 was significantly down-regulated in } \\
\text { Staphylococcus aureus-infected osteoblasts compared with untreated } \\
\text { control cells. Overexpression of miR-24 could reduce the effects of } \\
\text { Staphylococcus aureus }\end{array}$ & Jin et al., 2015 \\
\hline
\end{tabular}

MOI, Multiplicity of infection (number of bacteria per cell); MNCOs, Mouse neonate calvarial osteoblasts; NHOs, Normal human osteoblasts; MC3T3-E1, Mouse calvaria cell line; MG-63, Human osteosarcoma cell line; SaoS-2, Human osteosarcoma cell line; hFOBs, Human fetal osteoblastic cell line; SV40 hOBs, Human osteoblastic cell line; Lab, Laboratory strains

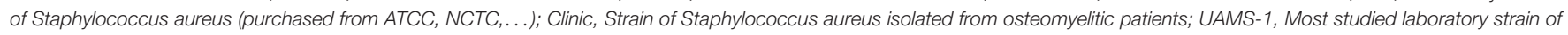
Staphylococcus aureus in bone infection models.

infected osteoblasts participate in the innate immune response in an attempt to clear the bacteria.

Osteoblasts are furthermore deemed to take part in the adaptive response to $S$. aureus. Infected osteoblasts up-regulate their release of IL-12 and CXCL10 (IP-10) - two molecules that recruit and activate Th1 lymphocyte-(Bost et al., 1999; Gasper et al., 2002). S. aureus-challenged osteoblasts are also able to express CD40 and MHC II, both implicated in the initiation of Th1 lymphocyte response (Schrum et al., 2003a,b). T lymphocytes secrete IFN- $\gamma$ - a hallmark of their activationwhile interacting with $S$. aureus-infected osteoblasts (Bost et al., 1999). There are no reports that confirm or exclude a role of other adaptive immune cells such as Th17 lymphocytes or dendritic cells in the response of osteoblasts to $S$. aureus. This needs to be further investigated to figure out whether if osteoblasts have a real role in adaptive immune responses in osteomyelitis or not.

An over-expression of TNF- $\alpha$, IL-1 $\beta$, and IL-18 mRNAs has been proved but the related-protein release has not been observed yet (Littlewood-Evans et al., 1997; Marriott et al., 2002), thus we cannot assess the impact of $S$. aureus-infected osteoblasts on inflammatory processes through these mediators. These findings once combined suggest that osteoblasts infected by $S$. aureus may participate in the innate immune response as well as in the adaptive immune response likely through the initiation of a Th1 lymphocyte response. This is sustained by current studies focusing on the mutual interplay between immune and bone systems designated as "osteoimmunology" (reviewed in Takayanagi, 2007, 2015).

In vitro experiments were nonetheless mostly performed using osteoblastic cell lines or marketed normal osteoblasts.
This may lead to an overstatement of the results, as such models diverge from the in vivo pathophysiological scenario. As described in Table 2, most of these results were obtained from different in vitro studies, with various conditions of cell culture or multiplicity of infection. The high multiplicities of infection or long time periods are globally needed for a release of cytokines/chemokines by osteoblasts. An increase of mRNA expression happens 6 or $8 \mathrm{~h}$ after the interaction of $S$. aureus with osteoblasts whereas the relative protein release starts from 24 to $48 \mathrm{~h}$ after the interaction. Those results justify the idea that inflammatory response by osteoblasts should not be pivotal in osteomyelitis caused by $S$. aureus. In addition, in vivo animal models of osteomyelitis showed that professional immune cells are rapidly recruited after infection (Yoshii et al., 2002; Horst et al., 2012; Niska et al., 2012). Quantifying the release of mediators especially produced by osteoblasts but not from recruited immune cells appears to be a hard thing to do. These recruited immune cells might likewise be more able to release large amounts of IL- $1 \beta$, IL- 6 and, TNF- $\alpha$ than osteoblasts. Thinking this through, we propose the osteal macrophages-also called OsteoMacs-to act as the initiator of inflammation in osteomyelitis. Those bone resident macrophages-which are different from osteoclast precursors-are localized into osteal tissue and play a role in both the bone formation and bone reparation and bone-related diseases as previously observed (Chang et al., 2008; Pettit et al., 2008). OsteoMacs seem to be more likely to initiate an inflammatory response in osteomyelitis than osteoblasts since they are professional resident immune cells. 


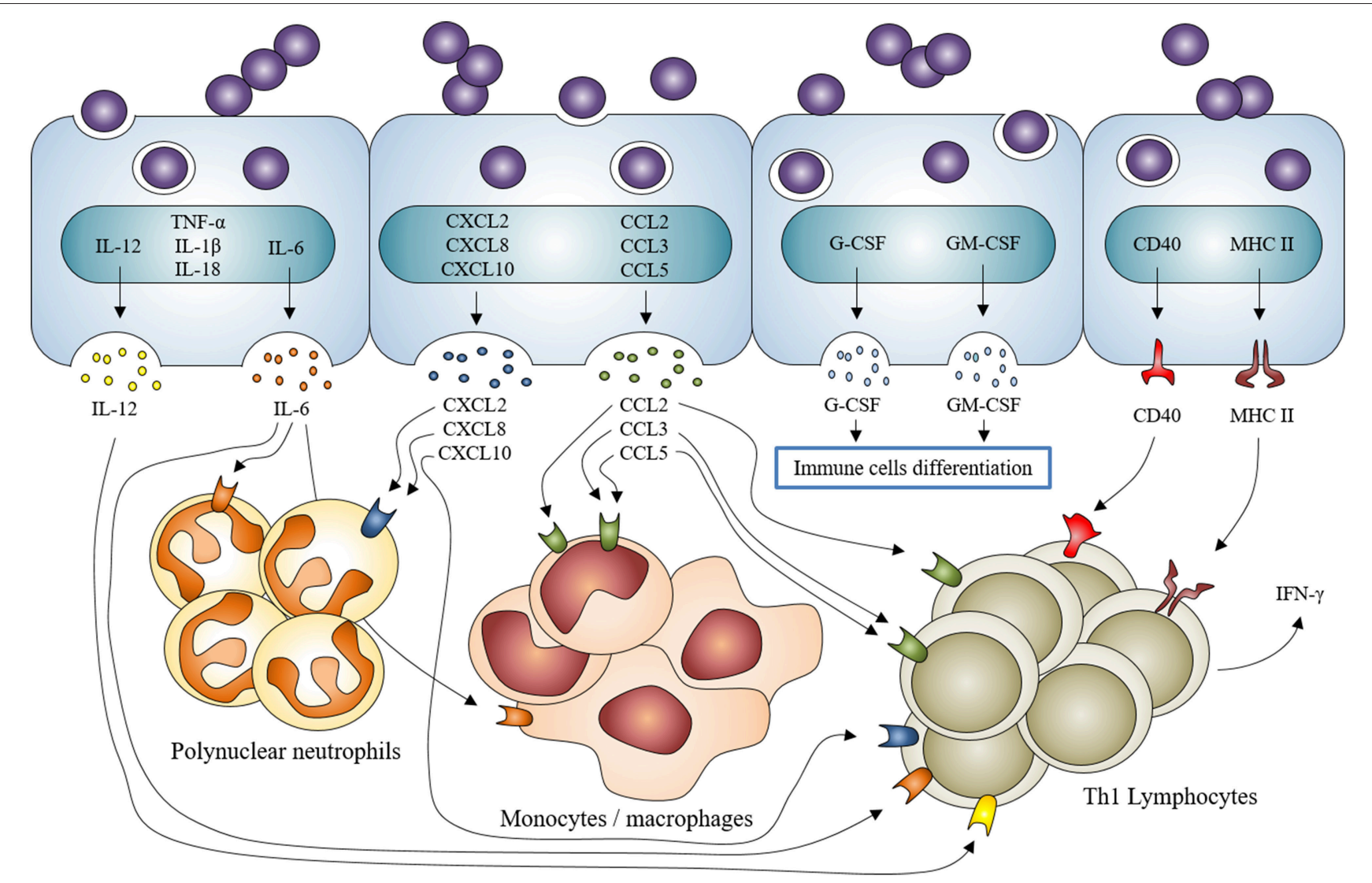

FIGURE 3 | Staphylococcus aureus induction of inflammatory mediator production by osteoblasts and participation in the recruitment/activation of innate and adaptive immune cells. Staphylococcus aureus interaction with osteoblasts increases the expression of cytokines IL-1 $\beta$, IL-18, TNF- $\alpha$, the production and release of IL-6, IL-12 and the expression and release of chemokines CXCL2, CXCL8, CXCL10, CCL2, CCL3, CCL5 and growth factors G-CSF and GM-CSF. It also increases the expression and production of CD40 and MHC II. All of this participates to the recruitment and activation of innate (neutrophils,

monocytes/macrophages) and adaptive (lymphocytes) immune cells.

\section{S. AUREUS IMPACT ON OSTEOBLAST ACTIVITY AND VIABILITY}

S. aureus can also induce bone loss as well as a production of inflammatory mediators from osteoblasts. This phenomenon is partially due to a decrease of osteoblast activity and to their death following bacterial insult. S. aureus is known to inhibit osteoblast activity and differentiation. Several studies have shown a decrease of proliferation, a decreased alkaline phosphatase activity, and a lower expression of BEM components such as type I collagen, osteocalcin, osteopontin, and osteonectin in in vitro models of S. aureus/osteoblast interaction (Claro et al., 2011; Widaa et al., 2012; Jin et al., 2013). S. aureus is also known to prevent the mineralization process, observed through a lower calcium deposition in infected osteoblast cultures compared to their non-infected counterparts (Claro et al., 2011; Jin et al., 2013; Sanchez et al., 2013; Chen et al., 2014).

Controversies arose from Somayaji et al. work in which they have figured out that UV-killed S. aureus coated on titanium alloys favored osteoblast adhesion, osteoblast differentiation and mineralization (Somayaji et al., 2010). These results in opposition with all the previous statements suggest that the effect of $S$. aureus on osteoblast activity is not totally elucidated. Jin et al. recently highlighted that effects of $S$. aureus on osteoblast activity could be dependent of microRNAs (Jin et al., 2015). Relationship between osteoblast response to $S$. aureus and the microRNAs production could be a new interesting approach to understand osteomyelitis at a cellular level and decipher which components are able to whether decrease or increase osteoblastic activity.

S. aureus can also cause apoptosis of osteoblasts regardless to specific osteoblastic activity. This is observed following $S$. aureus infection of various cell types including endothelial cells, epithelial cells or osteoblasts (Menzies and Kourteva, 1998; Kahl et al., 2000; Tucker et al., 2000). In S. aureus-infected osteoblasts, apoptosis appeared to be dependent on the release of the tumor necrosis factor-related apoptosis-inducing ligand (TRAIL; Alexander et al., 2001). TRAIL interacts with death receptors DR4 and DR5 expressed in infected osteoblasts (Young et al., 2011), leading to the induction of apoptotic pathways. In the situation of $S$. aureus-infected osteoblasts, an activation of the apoptosis intrinsic pathway through caspase-9 (Jin et al., 2013) and the extrinsic pathway through caspase- 8 was observed 
(Alexander et al., 2003), both of them leading to activation of caspase-3 and apoptosis (Claro et al., 2011; Figure 4).

Osteoblast death was also associated with above-cited toxins produced by $S$. aureus like PSM $\alpha, \operatorname{PSM} \beta$, and $\delta$-toxin (Cassat et al., 2013; Rasigade et al., 2013; Valour et al., 2015b). These virulence factors have a membrane-damaging activity which suggests that $S$. aureus-induced osteoblast death can also be independent of apoptosis. Non-apoptotic cell death has been observed in presence of $\alpha$-toxin-another membrane-damaging virulence factor of $S$. aureus - in an in vitro cell line model (Essmann et al., 2003).

Death induction in osteoblasts is an important feature of $S$. aureus-related osteomyelitis. On the one hand, it leads to lowered bone formation activity and on the other hand, the death of osteoblasts may allow the release of the intracellular viable $S$. aureus, which are able to re-infect surviving osteoblasts and exacerbate the infection (Ellington et al., 2003).

\section{S. AUREUS/OSTEOBLASTS INTERACTION AND OSTEOCLASTOGENESIS}

Bone loss in osteomyelitis is also caused by an increased formation and activation of osteoclasts in addition to the death of osteoblasts. A tight balance between bone formation by osteoblasts and bone resorption by osteoclasts is essential for the strength and integrity of bones. We have so far reviewed a role of $S$. aureus in decreasing osteoblast activity and inducing osteoblast death, hinting an impaired osteoblast/osteoclast balance necessary for proper bone formation.

Osteoblasts are producers of receptor activator of NF$\kappa \mathrm{B}$ ligand (RANK-L) and osteoprotegerin (OPG). RANK-L interacts with its receptor RANK on monocyte/macrophage precursors to drive their differentiation toward osteoclasts. OPG is a soluble decoy receptor that targets RANK-L to limit osteoclastogenesis (Boyle et al., 2003). In the case of $S$. aureus infection, osteoblasts increase their production of membrane-bound RANK-L and sRANK-L-a soluble and minor form of RANK-L-whereas OPG production by osteoblasts decreases following $S$. aureus infection despite an absence of modulation of the OPG mRNA synthesis (Somayaji et al., 2008; Claro et al., 2011; Young et al., 2011; Widaa et al., 2012; Figure 5). It is therefore thought that $S$. aureus is able to indirectly increase osteoclastogenesis as a result of its interaction with osteoblasts. An increase of prostaglandin E2 (PGE2) production has furthermore been demonstrated in $S$. aureus-infected osteoblasts (Somayaji et al., 2008). PGE2-a hormone-like molecule and enzymatic product of the cyclooxygenase 2 (Cox-2) - acts in an autocrine and paracrine manner to upregulate the production of RANK-L through activation of

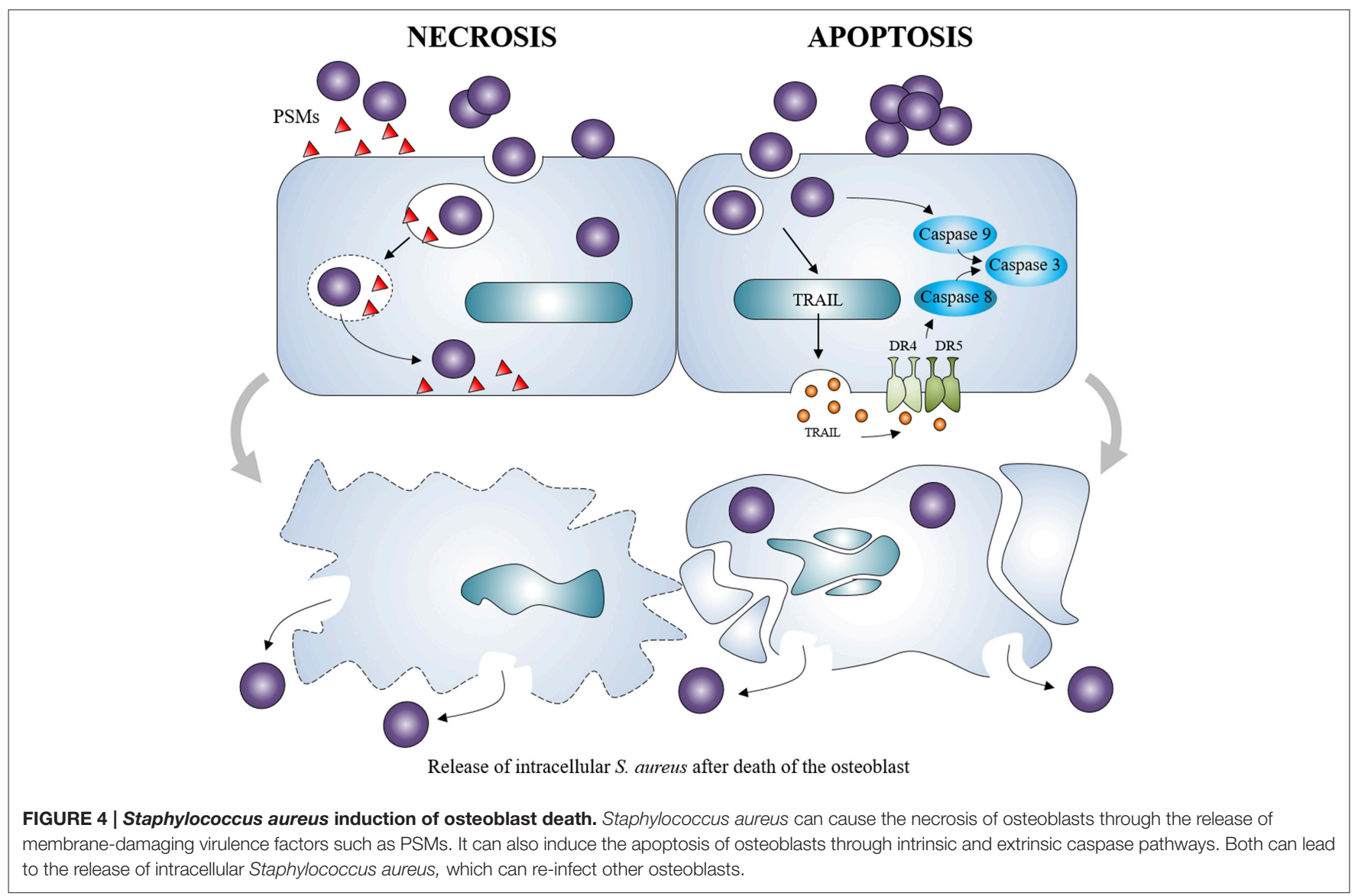




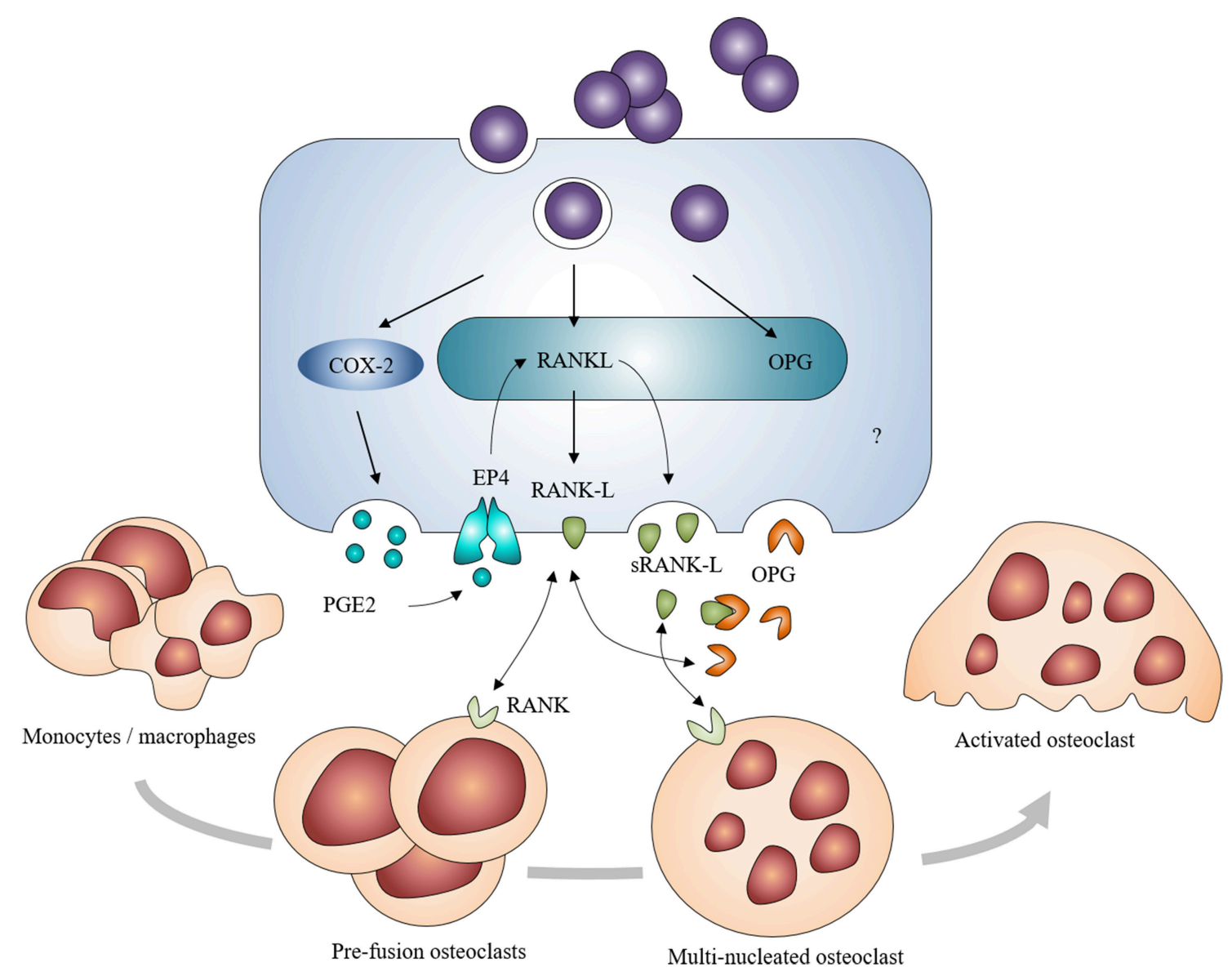

FIGURE 5 | Induction of osteoclastogenesis by Staphylococcus aureus-challenged osteoblasts. S. aureus-challenged osteoblasts increase their expression and production of RANK-L, directly or through the COX-2/PGE2 pathway. It leads to an excessive formation and activation of osteoclasts and to a severe bone resorption in addition to a decreased production of OPG.

the EP4 receptor in osteoblasts (Figure 5). PGE2 up-regulated by $S$. aureus thus acts as a complementary stimulating effect on osteoblasts to release osteoclastogenic factors (Johansen et al., 2012). Recent studies nevertheless showed that $S$. aureus or its components can also favor bone resorption through interaction with osteoclast cell lineage. $S$. aureus provoked the enhancement of the osteoclast differentiation and the release of pro-inflammatory cytokines (Kim et al., 2013). These cytokines enhanced the bone resorption capacity of uninfected mature osteoclasts and promoted osteoclastogenesis of the uninfected precursors (Trouillet-Assant et al., 2015). Further studies are yet needed to fully fathom the interactions between $S$. aureus and osteoclasts and the mechanisms involved in the latter interactions.

\section{OSTEOBLAST SELF-DEFENSE AGAINST S. AUREUS}

Infected osteoblasts can release AMPs in order to defend themselves against $S$. aureus. These molecules, mostly cationic, are secreted by various types of cells and are able to neutralize bacteria. They are classified in three categories: $\alpha$-defensins, $\beta$ defensins and cathelicidin-related molecules-with LL-37 as the only member in humans-(reviewed in Mansour et al., 2014). It was shown that human osteoblasts increase their release of human $\beta$-defensin (HBD) 2 and HBD-3 following stimulation by $S$. aureus culture supernatants, (Varoga et al., 2008, 2009). The release of MBD-14-the murine ortholog of HBD-3-was also seen in infected murine osteoblasts (Zhu et al., 2013). A higher expression of HBD-3 and MBD-14 was also found in human interfacial membrane surrounding implants infected by $S$. aureus and in a murine model of osteomyelitis, respectively (Zhu et al., 2014). LL-37 is moreover secreted by the human bone marrow mesenchymal stem cells (Krasnodembskaya et al., 2010) and described to exhibit a killing effect on S. aureus inside osteoblasts (Noore et al., 2013). The use of exogenous LL-37 in osteomyelitis is however uncertain as it might have deleterious effects on osteoblasts (Säll et al., 2013; Svensson et al., 2015). As for $\alpha$-defensins, their production is mostly attributed to neutrophils or Paneth cells, and not to osteoblasts or other stromal cells (Mansour et al., 2014). The use of exogenous AMPs 
could be a promising and effective way to treat osteomyelitis. Synthetic compounds similar to AMPs were produced and relevant as treatments toward bacterial infection, and notably in a S. aureus infection model (Nijnik et al., 2010). They can be added by the way to supports like titanium alloys, thus enlarging their possible use to fight against implant-associated osteomyelitis (Kazemzadeh-Narbat et al., 2013). Up to now, the emergence of resistance to AMPs was considered low, virtually because of the complexity of their mode of action (Jenssen et al., 2006). A recent review however highlights that $S$. aureus holds mechanisms of resistance to AMPs (Joo and Otto, 2015). As a matter of fact, we deem this moderates the brilliant future for AMPs in anti-staphylococcal treatments be it in bone or elsewhere.

\section{ANTIBIOTIC CHEMOTHERAPIES AT S. AUREUS/OSTEOBLASTS SPECIFIC SCALE}

Clinical guidelines for the treatment of osteomyelitis with $S$. aureus generally recommend the use of a combination of antibiotics consisting of penicillin $\mathrm{M}$-i.e., oxacillin-combined with an aminoglycoside-i.e., gentamicin-or to rifampicin. The uses of glycopeptide-i.e., vancomycin-combined with linezolid or rifampicin, of clindamycin combined with rifampicin, or of fluoroquinolone-i.e., ofloxacin-combined with rifampicin are considerable options for the treatment of osteomyelitis with meticillin-resistant S. aureus (MRSA; Lew and Waldvogel, 2004; Hatzenbuehler and Pulling, 2011; Osmon et al., 2013; Lima et al., 2014).

The internalization of $S$. aureus inside osteoblasts however represents a major challenge in the treatment of osteomyelitis. The ability of the recommended antibiotics to kill intracellular $S$. aureus is the cornerstone for relevant treatment of osteomyelitis. In this context, studies have assessed the effects of these antibiotics in in vitro models of infection. A treatment with gentamicin, vancomycin or daptomycin decrease the number of intra-osteoblastic bacteria, without totally eradicating them, even at high concentrations. The rifampicin used in clinical concentrations has on the contrary resulted to eradicate intracellular S. aureus inside cultured osteoblasts (Mohamed et al., 2014; Valour et al., 2015a). The treatment has to start but very early since a $12 \mathrm{~h}$-delayed rifampicin treatment of $S$. aureuschallenged osteoblasts significantly decreased its effectiveness in killing intracellular bacteria by 100 -fold (Ellington et al., 2006). In this case, the surface of $S$. aureus is altered after exposure to the intracellular osteoblast environment as Ellington et al. described it. A thick capsular material appears on intra-osteoblastic $S$. aureus that could explain the resistance to rifampicin. Specific mechanisms that describe the alteration of the surface of $S$. aureus by osteoblast intracellular environment have not been determined yet but we can suggest that SCVs may be involved in this phenomenon. One can say that further investigations need to be carried out. Combined therapy using rifampicin and ultrasound has been recently proposed to enhance the intracellular killing relevancy but it seemed that ultrasounds had a negative impact on the viability of cultured osteoblasts (Shi et al., 2013). This process is even more difficult to transpose to clinical applications.

Recent studies investigated the effect of tigecyclin, teicoplanin, ofloxacin, and linezolid. These antibiotics-which are recommended in the treatment of osteomyelitis-have an intermediate intracellular antimicrobial effectiveness, higher than gentamicin or vancomycin and lower or equivalent to rifampicin (Kreis et al., 2013; Valour et al., 2015a). Ofloxacin, daptomycin, and vancomycin were also deemed to limit intracellular SCVs emergence (Valour et al., 2015a). The concentration however used in antibiotic treatment is also a critical point. Sub-inhibitory concentrations of oxacillin, moxifloxacin, and linozelid increase the fibronectin-mediated binding of $S$. aureus whereas sub-inhibitory concentrations of rifampicin still have decreasing effects on its binding (Rasigade et al., 2011). Radezolid and naficillin-loaded nanoparticles have also been investigated for their ability to kill S. aureus inside cultured osteoblasts (Pillai et al., 2008; Lemaire et al., 2010). Radezolid has shown a higher bactericidal activity compared to linezolid and an effective killing of intracellular bacteria was observed with naficillin-loaded nanoparticles.

All these recent studies shed light on the importance of intraosteoblastic penetrance of antibiotics. This property is essential for the development of new therapeutics against osteomyelitis caused by $S$. aureus.

\section{CONCLUSION}

Osteoblast infection by $S$. aureus can be defined as a 4step process from mostly in vitro models. First, S. aureus binds to the BEM and to osteoblasts. Through attachment, $S$. aureus can be internalized and survive within the cell switching notably to a SCV phenotype. Then, S. aureus or its components may potentially modulate the production of cytokines, chemokines or AMPs, through binding to extracellular and/or intracellular receptors. Infection with $S$. aureus eventually induces inflammatory cell recruitment, which, combined with increased osteoclastogenesis and osteoblast death, leads to a massive bone loss (Figure 6).

Nevertheless, the defined role of infected osteoblasts in inflammatory response results from in vitro experiments that were mostly done with osteoblastic cell lines or marketed normal osteoblasts (Table 2) and diverges from the in vivo pathophysiological scenario. Cytokines/chemokines released by infected osteoblasts must only be a drop in the bucket compared to those released by neutrophils and macrophages/monocytes during osteomyelitis caused by $S$. aureus. From this point of view, osteoblasts thought to take part in global inflammatory response but without having a decisive role.

On the other side, internalization and intracellular persistence appears to us as the key stages of $S$. aureus/osteoblast interaction. Escape from intra-osteoblastic vesicle, switching to a SCV phenotype and osteoblast death following membrane damages are important phenomena to understand the evolution from acute to chronic osteomyelitis. 


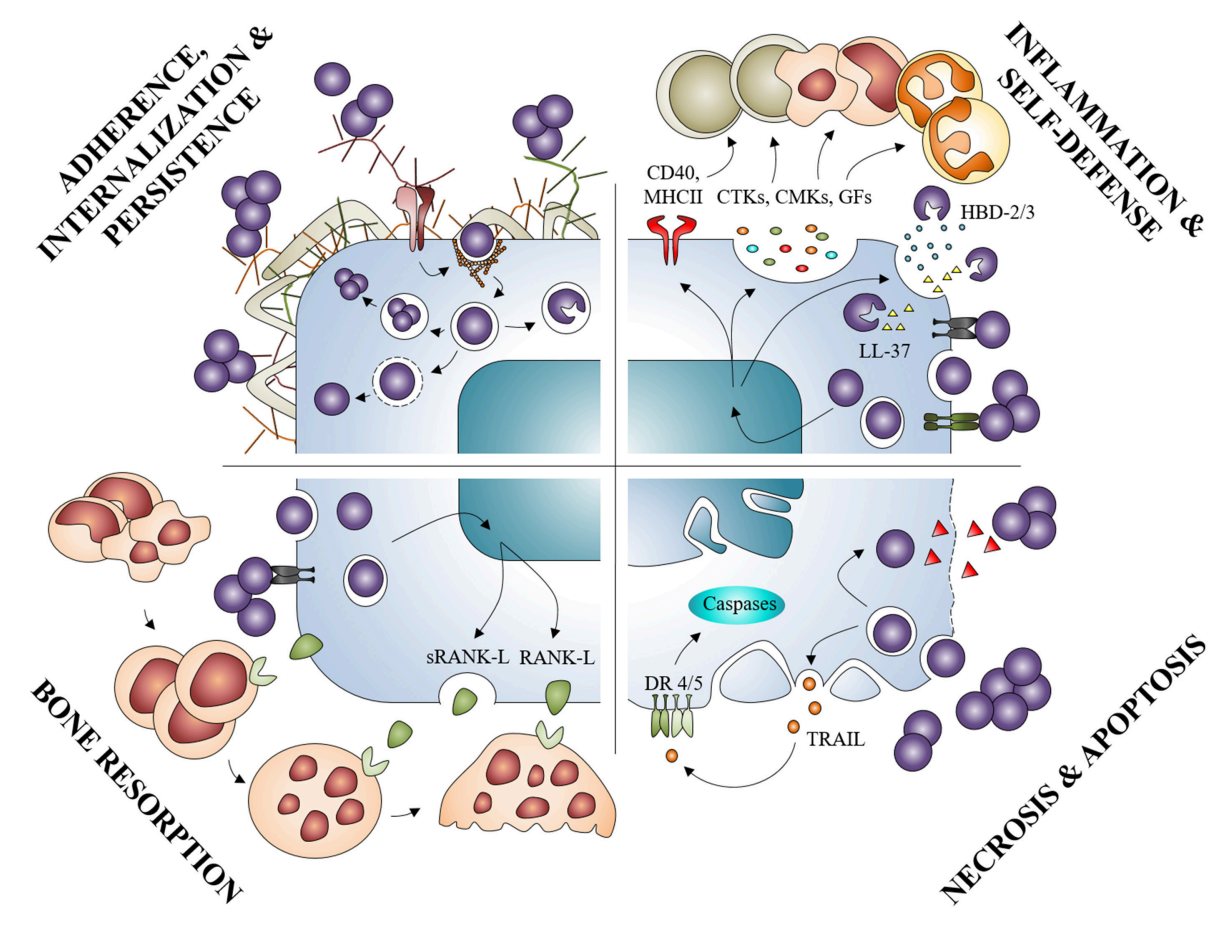

FIGURE 6 | Summary diagram of the osteoblasts responses in presence of Staphylococcus aureus. S. aureus can interact with osteoblasts and provoke: inflammation by increased release of mediators such as cytokines (CTKs), chemokines (CMKs), or growth factors (GFs); osteoblast self-defense by the production of AMPs (HBD-2/3, LL-37); osteoblasts death through apoptosis or necrosis; bone resorption by activation of the RANK/RANK-L complex.

The $S$. aureus infection of the osteoblast is in the end a very complex phenomenon with a myriad of actors (Figure 6). To focus on one specific step allows us to better understand a precise mechanism but does not reflect the complexity of the entire infectious process, in the same way that focusing only on osteoblasts and avoiding other cells from bone tissues limits and biases our understanding. The use of new research models is necessary to complete the information obtained from the previous osteoblast in vitro infection models.

It is clear to us that more investigations using patient isolated $S$. aureus/primary osteoblasts in vitro models are needed and that systemic in vivo models close to the human scenarios of infection need to be optimized to consider new therapeutic approaches for this disease of high morbidity. New treatments or preventive approaches need also to be developed so as to avoid the internalization of $S$. aureus inside osteoblasts, contain the local inflammatory process, and increase the osteoblasts selfdefense.

\section{REFERENCES}

Ahmed, S., Meghji, S., Williams, R. J., Henderson, B., Brock, J. H., and Nair, S. P. (2001). Staphylococcus aureus fibronectin binding proteins are essential for internalization by osteoblasts but do not account for differences in intracellular levels of bacteria. Infect. Immun. 69, 2872-2877. doi: 10.1128/IAI.69.5.28722877.2001

\section{AUTHOR CONTRIBUTIONS}

JJ compiled the publications and wrote the first drafts of the review under the supervision of his advisors FV and SG. All the authors contributed equally to the final submitted version.

\section{FUNDING}

$\mathrm{JJ}$ is the recipient of a fellowship from the French Ministry for Higher Education and Research-Ministère de l'Enseignement Supérieur et de la Recherche.

\section{ACKNOWLEDGMENTS}

The authors warmly thank Prof. S. M. Goyert (CUNY School of Medicine, New York, NY, USA) and D. Al Alam, PhD (Saban Research Institute of Childrens Hospital Los Angeles, Los Angeles, CA, USA) for having carefully proof read this manuscript.

Alexander, E. H., Bento, J. L., Hughes, F. M. Jr., Marriott, I., Hudson, M. C., and Bost, K. L. (2001). Staphylococcus aureus and Salmonella enterica serovar dublin induce tumor necrosis factor-related apoptosis-inducing ligand expression by normal mouse and human osteoblasts. Infect. Immun. 69, 1581-1586. doi: 10.1128/IAI.69.3.1581-1586.2001

Alexander, E. H., Rivera, F. A., Marriott, I., Anguita, J., Bost, K. L., and Hudson, M. C. (2003). Staphylococcus aureus - induced tumor necrosis factor - related 
apoptosis - inducing ligand expression mediates apoptosis and caspase-8 activation in infected osteoblasts. BMC Microbiol. 3:5. doi: 10.1186/14712180-3-5

Atshan, S. S., Nor Shamsudin, M., Sekawi, Z., Lung, L. T. T., Hamat, R. A., Karunanidhi, A. et al. (2012). Prevalence of adhesion and regulation of biofilmrelated genes in different clones of Staphylococcus aureus. J. Biomed. Biotechnol. 2012:976972. doi: 10.1155/2012/976972

Bosse, M. J., Gruber, H. E., and Ramp, W. K. (2005). Internalization of bacteria by osteoblasts in a patient with recurrent, long-term osteomyelitis. A case report. J. Bone Joint Surg. Am. 87, 1343-1347. doi: 10.2106/JBJS.D.02649

Bost, K. L., Bento, J. L., Ellington, J. K., Marriott, I., and Hudson, M. C. (2000). Induction of colony-stimulating factor expression following Staphylococcus or Salmonella interaction with mouse or human osteoblasts. Infect. Immun. 68, 5075-5083. doi: 10.1128/IAI.68.9.5075-5083.2000

Bost, K. L., Bento, J. L., Petty, C. C., Schrum, L. W., Hudson, M. C., and Marriott, I. (2001). Monocyte chemoattractant protein-1 expression by osteoblasts following infection with Staphylococcus aureus or Salmonella. J. Interferon Cytokine Res. 21, 297-304. doi: 10.1089/107999001300177484

Bost, K. L., Ramp, W. K., Nicholson, N. C., Bento, J. L., Marriott, I., and Hudson, M. C. (1999). Staphylococcus aureus infection of mouse or human osteoblasts induces high levels of interleukin-6 and interleukin-12 production. J. Infect. Dis. 180, 1912-1920. doi: 10.1086/315138

Boyle, W. J., Simonet, W. S., and Lacey, D. L. (2003). Osteoclast differentiation and activation. Nature 423, 337-342. doi: 10.1038/nature01658

Campoccia, D., Speziale, P., Ravaioli, S., Cangini, I., Rindi, S., Pirini, V., et al. (2009). The presence of both bone sialoprotein-binding protein gene and collagen adhesin gene as a typical virulence trait of the major epidemic cluster in isolates from orthopedic implant infections. Biomaterials 30, 6621-6628. doi: 10.1016/j.biomaterials.2009.08.032

Cassat, J. E., Hammer, N. D., Campbell, J. P., Benson, M. A., Perrien, D. S., Mrak, L. N., et al. (2013). A secreted bacterial protease tailors the Staphylococcus aureus virulence repertoire to modulate bone remodeling during osteomyelitis. Cell Host Microbe 13, 759-772. doi: 10.1016/j.chom.2013.05.003

Chang, M. K., Raggatt, L.-J., Alexander, K. A., Kuliwaba, J. S., Fazzalari, N. L., Schroder, K., et al. (2008). Osteal tissue macrophages are intercalated throughout human and mouse bone lining tissues and regulate osteoblast function in vitro and in vivo. J. Immunol. 181, 1232-1244. doi: 10.4049/jimmunol.181.2.1232

Chauhan, V. S., and Marriott, I. (2010). Differential roles for NOD2 in osteoblast inflammatory immune responses to bacterial pathogens of bone tissue. J. Med. Microbiol. 59(Pt 7), 755-762. doi: 10.1099/jmm.0.015859-0

Chen, Q., Hou, T., Luo, F., Wu, X., Xie, Z., and Xu, J. (2014). Involvement of tolllike receptor 2 and pro-apoptotic signaling pathways in bone remodeling in osteomyelitis. Cell. Physiol. Biochem. 34, 1890-1900. doi: 10.1159/000366387

Choe, H., Narayanan, A. S., Gandhi, D. A., Weinberg, A., Marcus, R. E., Lee, Z., et al. (2015). Immunomodulatory peptide IDR-1018 decreases implant infection and preserves osseointegration. Clin. Orthop. Relat. Res. 473, 2898-2907. doi: 10.1007/s11999-015-4301-2

Claro, T., Widaa, A., McDonnell, C., Foster, T. J., O’Brien, F. J., and Kerrigan, S. W. (2013). Staphylococcus aureus protein A binding to osteoblast tumour necrosis factor receptor 1 results in activation of nuclear factor kappa B and release of interleukin-6 in bone infection. Microbiology 159(Pt 1), 147-154. doi: 10.1099/mic.0.063016-0

Claro, T., Widaa, A., O'Seaghdha, M., Miajlovic, H., Foster, T. J., O’Brien, F. J., et al. (2011). Staphylococcus aureus protein A binds to osteoblasts and triggers signals that weaken bone in osteomyelitis. PLoS ONE 6:e18748. doi: 10.1371/journal.pone. 0018748

Dallas, S. L., and Bonewald, L. F. (2010). Dynamics of the transition from osteoblast to osteocyte. Ann. N.Y. Acad. Sci. 1192, 437-443. doi: 10.1111/j.17496632.2009.05246.x

Dapunt, U., Maurer, S., Giese, T., Gaida, M. M., and Hänsch, G. M. (2014). The macrophage inflammatory proteins MIP1 $\alpha$ (CCL3) and MIP2 $\alpha$ (CXCL2) in implant-associated osteomyelitis: linking Inflammation to Bone degradation. Mediat. Inflamm. 2014:728619. doi: 10.1155/2014/728619

Dhanoa, A., Singh, V. A., Mansor, A., Yusof, M. Y., Lim, K.-T., and Thong, K.-L. (2012). Acute haematogenous community-acquired methicillin-resistant Staphylococcus aureus osteomyelitis in an adult: case report and review of literature. BMC Infect. Dis. 12:270. doi: 10.1186/1471-2334-12-270
Dziewanowska, K., Patti, J. M., Deobald, C. F., Bayles, K. W., Trumble, W. R., and Bohach, G. A. (1999). Fibronectin binding protein and host cell tyrosine kinase are required for internalization of Staphylococcus aureus by epithelial cells. Infect. Immun. 67, 4673-4678.

Ecarot-Charrier, B., Glorieux, F. H., van der Rest, M., and Pereira, G. (1983). Osteoblasts isolated from mouse calvaria initiate matrix mineralization in culture. J. Cell Biol. 96, 639-643.

Edwards, J. R., and Mundy, G. R. (2011). Advances in osteoclast biology: old findings and new insights from mouse models. Nat. Rev. Rheumatol. 7, 235-243. doi: 10.1038/nrrheum.2011.23

Elasri, M. O., Thomas, J. R., Skinner, R. A., Blevins, J. S., Beenken, K. E., Nelson, C. L., et al. (2002). Staphylococcus aureus collagen adhesin contributes to the pathogenesis of osteomyelitis. Bone 30, 275-280. doi: 10.1016/S87563282(01)00632-9

Ellington, J. K., Elhofy, A., Bost, K. L., and Hudson, M. C. (2001). Involvement of mitogen-activated protein kinase pathways in Staphylococcus aureus invasion of normal osteoblasts. Infect. Immun. 69, 5235-5242. doi: 10.1128/IAI.69.9.52355242.2001

Ellington, J. K., Harris, M., Hudson, M. C., Vishin, S., Webb, L. X., and Sherertz, R. (2006). Intracellular Staphylococcus aureus and antibiotic resistance: implications for treatment of staphylococcal osteomyelitis. J. Orthop. Res. 24, 87-93. doi: 10.1002/jor.20003

Ellington, J. K., Harris, M., Webb, L., Smith, B., Smith, T., Tan, K., et al. (2003). Intracellular Staphylococcus aureus. A mechanism for the indolence of osteomyelitis. J. Bone Joint Surg. Br. 85, 918-921. doi: 10.1302/0301620X.85B6.13509

Ellington, J. K., Reilly, S. S., Ramp, W. K., Smeltzer, M. S., Kellam, J. F., and Hudson, M. C. (1999). Mechanisms of Staphylococcus aureus invasion of cultured osteoblasts. Microb. Pathog. 26, 317-323. doi: 10.1006/mpat.1999.0272

Essmann, F., Bantel, H., Totzke, G., Engels, I. H., Sinha, B., Schulze-Osthoff, K., et al. (2003). Staphylococcus aureus alpha-toxin-induced cell death: predominant necrosis despite apoptotic caspase activation. Cell Death Differ. 10, 1260-1272. doi: 10.1038/sj.cdd.4401301

Fisher, L. W., McBride, O. W., Termine, J. D., and Young, M. F. (1990). Human bone sialoprotein. Deduced protein sequence and chromosomal localization. J. Biol. Chem. 265, 2347-2351.

Fournier, B. (2012). The function of TLR2 during staphylococcal diseases. Front. Cell. Infect. Microbiol. 2:167. doi: 10.3389/fcimb.2012.00167

Gasper, N. A., Petty, C. C., Schrum, L. W., Marriott, I., and Bost, K. L. (2002). Bacterium-induced CXCL10 secretion by osteoblasts can be mediated in part through toll-like receptor 4. Infect. Immun. 70, 4075-4082. doi: 10.1128/IAI.70.8.4075-4082.2002

Giese, B., Glowinski, F., Paprotka, K., Dittmann, S., Steiner, T., Sinha, B., et al. (2011). Expression of $\delta$-toxin by Staphylococcus aureus mediates escape from phago-endosomes of human epithelial and endothelial cells in the presence of $\beta$-toxin. Cell. Microbiol. 13, 316-329. doi: 10.1111/j.1462-5822.2010.0 1538.x

Gillaspy, A. F., Patti, J. M., and Smeltzer, M. S. (1997). Transcriptional regulation of the Staphylococcus aureus collagen adhesin gene, Cna. Infect. Immun. 65, 1536-1540.

Gómez, M. I., Lee, A., Reddy, B., Muir, A., Soong, G., Pitt, A., et al. (2004). Staphylococcus aureus protein A induces airway epithelial inflammatory responses by activating TNFR1. Nat. Med. 10, 842-848. doi: 10.1038/nm1079

Grosz, M., Kolter, J., Paprotka, K., Winkler, A.-C., Schäfer, D., Chatterjee, S. S., et al. (2014). Cytoplasmic replication of Staphylococcus aureus upon phagosomal escape triggered by phenol-soluble modulin $\alpha$. Cell. Microbiol. 16, 451-465. doi: $10.1111 / \mathrm{cmi} .12233$

Grzesik, W. J., and Robey, P. G. (1994). Bone matrix RGD glycoproteins: immunolocalization and interaction with human primary osteoblastic bone cells in vitro. J. Bone Miner. Res. 9, 487-496. doi: 10.1002/jbmr.5650090408

Hamza, T., and Li, B. (2014). Differential responses of osteoblasts and macrophages upon Staphylococcus aureus infection. BMC Microbiol. 14:207. doi: 10.1186/s12866-014-0207-5

Hatzenbuehler, J., and Pulling, T. J. (2011). Diagnosis and management of osteomyelitis. Am. Fam. Physician 84, 1027-1033.

Heilmann, C. (2011). "Adhesion mechanisms of staphylococci," in Bacterial Adhesion: Advances in Experimental Medicine and Biology, Vol. 715, eds D. Linke and A. Goldman (Dordrecht: Springer), 105-123. 
Hirschhausen, N., Schlesier, T., Schmidt, M. A., Götz, F., Peters, G., and Heilmann, C. (2010). A novel staphylococcal internalization mechanism involves the major autolysin Atl and heat shock cognate protein HSC70 as host cell receptor. Cell. Microbiol. 12, 1746-1764. doi: 10.1111/j.1462-5822.2010.01506.x

Hogan, A., Heppert, V. G., and Suda, A. J. (2013). Osteomyelitis. Arch. Orthop. Trauma Surg. 133, 1183-1196. doi: 10.1007/s00402-013-1785-7

Horst, S. A., Hoerr, V., Beineke, A., Kreis, C., Tuchscherr, L., Kalinka, J., et al. (2012). A novel mouse model of Staphylococcus aureus chronic osteomyelitis that closely mimics the human infection: an integrated view of disease pathogenesis. Am. J. Pathol. 181, 1206-1214. doi: 10.1016/j.ajpath.2012.07.005

Hudson, M. C., Ramp, W. K., Nicholson, N. C., Williams, A. S., and Nousiainen, M. T. (1995). Internalization of Staphylococcus aureus by cultured osteoblasts. Microb. Pathog. 19, 409-419. doi: 10.1006/mpat.1995.0075

Jauregui, C. E., Mansell, J. P., Jepson, M. A., and Jenkinson, H. F. (2013). Differential interactions of Streptococcus gordonii and Staphylococcus aureus with cultured osteoblasts. Mol. Oral Microbiol. 28, 250-266. doi: 10.1111/omi.12022

Jenssen, H., Hamill, P., and Hancock, R. E. W. (2006). Peptide antimicrobial agents. Clin. Microbiol. Rev. 19, 491-511. doi: 10.1128/CMR.00056-05

Jevon, M., Guo, C., Ma, B., Mordan, N., Nair, S. P., Harris, M., et al. (1999). Mechanisms of internalization of Staphylococcus aureus by cultured human osteoblasts. Infect. Immun. 67, 2677-2681.

Jin, T., Lu, Y., He, Q. X., Wang, H., Li, B. F., Zhu, L. Y., et al. (2015). The role of MicroRNA, miR-24, and Its target CHI3L1 in osteomyelitis caused by Staphylococcus aureus. J. Cell. Biochem. 116, 2804-2813. doi: 10.1002/jcb. 25225

Jin, T., Zhu, Y. L., Li, J., Shi, J., He, X. Q., Ding, J., et al. (2013). Staphylococcal protein A, Panton-Valentine leukocidin and coagulase aggravate the bone loss and bone destruction in osteomyelitis. Cell. Physiol. Biochem. 32, 322-33. doi: $10.1159 / 000354440$

Johansen, L. K., Iburg, T. M., Nielsen, O. L., Leifsson, P. S., Dahl-Petersen, K., Koch, J., et al. (2012). Local osteogenic expression of cyclooxygenase-2 and systemic response in porcine models of osteomyelitis. Prostaglandins Other Lipid Mediat. 97, 103-108. doi: 10.1016/j.prostaglandins.2012.01.002

Jönsson, K., McDevitt, D., McGavin, M. H., Patti, J. M., and Höök, M. (1995). Staphylococcus aureus expresses a major histocompatibility complex class II analog. J. Biol. Chem. 270, 21457-21460. doi: 10.1074/jbc.270.37. 21457

Joo, H. S., and Otto, M. (2015). Mechanisms of resistance to antimicrobial peptides in staphylococci. Biochim. Biophys. Acta 1848(11 Pt B), 3055-3061. doi: 10.1016/j.bbamem.2015.02.009

Kahl, B. C., Goulian, M., van Wamel, W., Herrmann, M., Simon, S. M., Kaplan, G., et al. (2000). Staphylococcus aureus RN6390 replicates and induces apoptosis in a pulmonary epithelial cell line. Infect. Immun. 68, 5385-5392. doi: 10.1128/IAI.68.9.5385-5392.2000

Kalinka, J., Hachmeister, M., Geraci, J., Sordelli, D., Hansen, U., Niemann, S., et al. (2014). Staphylococcus aureus isolates from chronic osteomyelitis are characterized by high host cell invasion and intracellular adaptation, but still induce inflammation. Int. J. Med. Microbiol. 304, 1038-1049. doi: 10.1016/j.ijmm.2014.07.013

Kawai, T., and Akira, S. (2010). The role of pattern-recognition receptors in innate immunity: update on toll-like receptors. Nat. Immunol. 11, 373-384. doi: 10.1038/ni. 1863

Kazemzadeh-Narbat, M., Lai, B. F. L., Ding, C., Kizhakkedathu, J. N., Hancock, R. E. W., and Wang, R. (2013). Multilayered coating on titanium for controlled release of antimicrobial peptides for the prevention of implant-associated infections. Biomaterials 34, 5969-5977. doi: 10.1016/j.biomaterials.2013.04.036

Khalil, H., Williams, R. J., Stenbeck, G., Henderson, B., Meghji, S., and Nair, S. P. (2007). Invasion of bone cells by Staphylococcus epidermidis. Microbes Infect. 9, 460-465. doi: 10.1016/j.micinf.2007.01.002

Kikuchi, T., Matsuguchi, T., Tsuboi, N., Mitani, A., Tanaka, S., Matsuoka, M., et al. (2001). Gene expression of osteoclast differentiation factor is induced by lipopolysaccharide in mouse osteoblasts via toll-like receptors. J. Immunol. 166, 3574-3579. doi: 10.4049/jimmunol.166.5.3574

Kim, J., Yang, J., Park, O.-J., Kang, S.-S., Kim, W.-S., Kurokawa, K., et al. (2013). Lipoproteins are an important bacterial component responsible for bone destruction through the induction of osteoclast differentiation and activation. J. Bone Miner. Res. 28, 2381-2391. doi: 10.1002/jbmr.1973
Kim, P. H., and Leopold, S. S. (2012). In brief: Gustilo-Anderson classification. [corrected]. Clin. Orthop. Relat. Res. 470, 3270-3274. doi: 10.1007/s11999-0122376-6

Kintarak, S., Whawell, S. A., Speight, P. M., Packer, S., and Nair, S. P. (2004). Internalization of Staphylococcus aureus by human keratinocytes. Infect. Immun. 72, 5668-5675. doi: 10.1128/IAI.72.10.5668-5675.2004

Krasnodembskaya, A., Song, Y., Fang, X., Gupta, N., Serikov, V., Lee, J. W., et al. (2010). Antibacterial effect of human mesenchymal stem cells is mediated in part from secretion of the antimicrobial peptide LL-37. Stem Cells 28, 2229-2238. doi: 10.1002/stem.544

Kreis, C. A., Raschke, M. J., Roßlenbroich, S. B., Tholema-Hans, N., Löffler, B., and Fuchs, T. (2013). Therapy of intracellular Staphylococcus aureus by tigecyclin. BMC Infect. Dis. 13:267. doi: 10.1186/1471-2334-13-267

Lemaire, S., Kosowska-Shick, K., Appelbaum, P. C., Verween, G., Tulkens, P. M., and Van Bambeke, F. (2010). Cellular pharmacodynamics of the novel biaryloxazolidinone radezolid: studies with infected phagocytic and nonphagocytic cells, using Staphylococcus aureus, Staphylococcus epidermidis, Listeria monocytogenes, and Legionella pneumophila. Antimicrob. Agents Chemother. 54, 2549-2559. doi: 10.1128/AAC.01724-09

Lew, D. P., and Waldvogel, F. A. (2004). Osteomyelitis. Lancet 364, 369-379. doi: 10.1016/S0140-6736(04)16727-5

Lima, A. L., Oliveira, P. R., Carvalho, V. C., Cimerman, S., Savio, E., and Diretrizes Panamericanas para el Tratamiento de las Osteomielitis e Infecciones de Tejidos Blandos Group (2014). Recommendations for the treatment of osteomyelitis. Braz. J. Infect. Dis. 18, 526-534. doi: 10.1016/j.bjid.2013.12.005

Littlewood-Evans, A. J., Hattenberger, M. R., Lüscher, C., Pataki, A., Zak, O., and O'Reilly, T. (1997). Local expression of tumor necrosis factor alpha in an experimental model of acute osteomyelitis in rats. Infect. Immun. 65, 3438-3443.

Lowy, F. D. (1998). Staphylococcus aureus infections. N. Engl. J. Med. 339, 520-532. doi: 10.1056/NEJM199808203390806

Madrazo, D. R., Tranguch, S. L., and Marriott, I. (2003). Signaling via toll-like receptor 5 can initiate inflammatory mediator production by murine osteoblasts. Infect. Immun. 71, 5418-5421. doi: 10.1128/IAI.71.9.54185421.2003

Mansour, S. C., Pena, O. M., and Hancock, R. E. W. (2014). Host defense peptides: front-line immunomodulators. Trends Immunol. 35, 443-450. doi: 10.1016/j.it.2014.07.004

Marriott, I., Hughes F. M. Jr., and Bost, K. L. (2002). Bacterial infection of osteoblasts induces interleukin-1beta and interleukin-18 transcription but not protein synthesis. J. Interferon Cytokine Res. 22, 1049-1055. doi: $10.1089 / 107999002760624288$

Marriott, I., Rati, D. M., McCall, S. H., and Tranguch, S. L. (2005). Induction of Nod1 and Nod2 intracellular pattern recognition receptors in murine osteoblasts following bacterial challenge. Infect. Immun. 73, 2967-2973. doi: 10.1128/IAI.73.5.2967-2973.2005

McCall, S. H., Sahraei, M., Young, A. B., Worley, C. S., Duncan, J. A., Ting, J. P. Y., et al. (2008). Osteoblasts express NLRP3, a nucleotide-binding domain and leucine-rich repeat region containing receptor implicated in bacterially induced cell death. J. Bone Miner. Res. 23, 30-40. doi: 10.1359/jbmr.071002

Menzies, B. E., and Kourteva, I. (1998). Internalization of Staphylococcus aureus by endothelial cells induces apoptosis. Infect. Immun. 66, 5994-98.

Mohamed, W., Sommer, U., Sethi, S., Domann, E., Thormann, U., Schütz, I., et al. (2014). Intracellular proliferation of Staphylococcus aureus in osteoblasts and effects of rifampicin and gentamicin on Staphylococcus aureus intracellular proliferation and survival. Eur. Cells Mater. 28, 258-268.

Montanaro, L., Arciola, C. R., Baldassarri, L., and Borsetti, E. (1999). Presence and expression of collagen adhesin gene (cna) and slime production in Staphylococcus aureus strains from orthopaedic prosthesis infections. Biomaterials 20, 1945-1949. doi: 10.1016/S0142-9612(99)00099-X

Montanaro, L., Speziale, P., Campoccia, D., Ravaioli, S., Cangini, I., Pietrocola, G., et al. (2011). Scenery of Staphylococcus implant infections in orthopedics. Future Microbiol. 6, 1329-1349. doi: 10.2217/fmb.11.117

Nair, S. P., Bischoff, M., Senn, M. M., and Berger-Bächi, B. (2003). The sigma B regulon influences internalization of Staphylococcus aureus by osteoblasts. Infect. Immun. 71, 4167-4170. doi: 10.1128/IAI.71.7.4167-4170.2003

Nijnik, A., Madera, L., Ma, S., Waldbrook, M., Elliott, M. R., Easton, D. M., et al. (2010). Synthetic cationic peptide IDR-1002 provides protection against 
bacterial infections through chemokine induction and enhanced leukocyte recruitment. J. Immunol. 184, 2539-2550. doi: 10.4049/jimmunol.0901813

Ning, R., Zhang, X., Guo, X., and Li, Q. (2010). Attachment of Staphylococcus aureus is required for activation of nuclear factor kappa B in human osteoblasts. Acta Biochim. Biophys. Sin. 42, 883-892. doi: 10.1093/abbs/gmq096

Ning, R., Zhang, X., Guo, X., and Li, Q. (2011). Staphylococcus aureus regulates secretion of interleukin- 6 and monocyte chemoattractant protein-1 through activation of nuclear factor kappa B signaling pathway in human osteoblasts. Braz. J. Infect. Dis. 15, 189-194. doi: 10.1016/S1413-8670(11)70173-8

Niska, J. A., Meganck, J. A., Pribaz, J. R., Shahbazian, J. H., Lim, E., Zhang, N., et al. (2012). Monitoring bacterial burden, inflammation and bone damage longitudinally using optical and $\mu \mathrm{CT}$ imaging in an orthopaedic implant infection in mice. PLoS ONE 7:e47397. doi: 10.1371/journal.pone.0047397

Noore, J., Noore, A., and Li, B. (2013). Cationic antimicrobial peptide LL-37 is effective against both extra- and intracellular Staphylococcus aureus. Antimicrob. Agents Chemother. 57, 1283-1290. doi: 10.1128/AAC.0 $1650-12$

Ogawa, S. K., Yurberg, E. R., Hatcher, V. B., Levitt, M. A., and Lowy, F. D. (1985). Bacterial adherence to human endothelial cells in vitro. Infect. Immun. 50, 218-224.

Osmon, D. R., Berbari, E. F., Berendt, A. R., Lew, D., Zimmerli, W., Steckelberg, J. M., et al. (2013). Diagnosis and management of prosthetic joint infection: clinical practice guidelines by the infectious diseases society ofaamerica. Clin. Infect. Dis. 56, e1-e25. doi: 10.1093/cid/cis803

Otsuka, T., Saito, K., Dohmae, S., Takano, T., Higuchi, W., Takizawa, Y., et al. (2006). Key adhesin gene in community-acquired methicillin-resistant Staphylococcus aureus. Biochem. Biophys. Res. Commun. 346, 1234-1244. doi: 10.1016/j.bbrc.2006.06.038

Peacock, S. J., Foster, T. J., Cameron, B. J., and Berendt, A. R. (1999), Bacterial fibronectin-binding proteins and endothelial cell surface fibronectin mediate adherence of Staphylococcus aureus to resting human endothelial cells. Microbiology 145, 3477-3486. doi: 10.1099/00221287-145-12-3477

Pettit, A. R., Chang, M. K., Hume, D. A., and Raggatt, L. J. (2008). Osteal macrophages: a new twist on coupling during bone dynamics. Bone 43, 976-982. doi: 10.1016/j.bone.2008.08.128

Pillai, R. R., Somayaji, S. N., Rabinovich, M., Hudson, M. C., and Gonsalves, K. E. (2008). Nafcillin-loaded PLGA nanoparticles for treatment of osteomyelitis. Biomed. Mater. 3:034114. doi: 10.1088/1748-6041/3/3/034114

Post, V., Wahl, P., Uçkay, I., Ochsner, P., Zimmerli, W., Corvec, S., et al. (2014). Phenotypic and genotypic characterisation of Staphylococcus aureus causing musculoskeletal infections. Int. J. Med. Microbiol. 304, 565-576. doi: 10.1016/j.ijmm.2014.03.003

Proctor, R. A., Kriegeskorte, A., Kahl, B. C., Becker, K., Löffler, B., and Peters, G. (2014). Staphylococcus aureus small colony variants (SCVs): a road map for the metabolic pathways involved in persistent infections. Front. Cell. Infect. Microbiol. 4:99. doi: 10.3389/fcimb.2014.00099

Proctor, R. A., von Eiff, C., Kahl, B. C., Becker, K., McNamara, P., Herrmann, M., et al. (2006). Small colony variants: a pathogenic form of bacteria that facilitates persistent and recurrent infections. Nat. Rev. Microbiol. 4, 295-305. doi: $10.1038 /$ nrmicrol384

Rasigade, J. P., Moulay, A., Lhoste, Y., Tristan, A., Bes, M., Vandenesch, F., et al. (2011). Impact of sub-inhibitory antibiotics on fibronectin-mediated host cell adhesion and invasion by Staphylococcus aureus. BMC Microbiol. 11:263. doi: 10.1186/1471-2180-11-263

Rasigade, J. P., Trouillet-Assant, S., Ferry, T., Diep, B. A., Sapin, A., Lhoste, Y., et al. (2013). PSMs of hypervirulent Staphylococcus aureus act as intracellular toxins that kill infected osteoblasts. PLOS ONE 8:e63176. doi: 10.1371/journal.pone.0063176

Reilly, S. S., Hudson, M. C., Kellam, J. F., and Ramp, W. K. (2000). In vivo internalization of Staphylococcus aureus by embryonic chick osteoblasts. Bone 26, 63-70. doi: 10.1016/S8756-3282(99)00239-2

Reott, M. A., Ritchie-Miller S. L., Anguita, J., and Hudson, M. C. (2008). TRAIL expression is induced in both osteoblasts containing intracellular Staphylococcus aureus and uninfected osteoblasts in infected cultures. FEMS Microbiol. Lett. 278, 185-192. doi: 10.1111/j.1574-6968.2007.00988.x

Rydén, C., Yacoub, A. I., Maxe, I., Heinegård, D., Oldberg, A., Franzén, A., et al. (1989). Specific binding of bone sialoprotein to Staphylococcus aureus isolated from patients with osteomyelitis. Eur. J. Biochem. 184, 331-336.
Säll, J., Carlsson, M., Gidlöf, O., Holm, A., Humlén, J., Ohman, J., et al. (2013). The antimicrobial peptide LL-37 alters human osteoblast $\mathrm{Ca}^{2+}$ handling and induces $\mathrm{Ca}^{2+-}$ independent apoptosis. J. Innate Immun. 5, 290-300. doi: $10.1159 / 000346587$

Sanchez, C. J. Jr., Ward, C. L., Romano, D. R., Hurtgen, B. J., Hardy, S. K., Woodbury, R. L., et al. (2013). Staphylococcus aureus biofilms decrease osteoblast viability, inhibits osteogenic differentiation, and increases bone resorption in vitro. BMC Musculoskelet. Disord. 14:187. doi: 10.1186/14712474-14-187

Schrum, L. W., Bost, K. L., Hudson, M. C., and Marriott, I. (2003a). Bacterial infection induces expression of functional MHC Class II molecules in murine and human osteoblasts. Bone 33, 812-821. doi: 10.1016/S8756-3282(03) 00265-5

Schrum, L. W., Marriott, I., Butler, B. R., Thomas, E. K., Hudson, M. C., and Bost, K. L. (2003b). Functional CD40 expression induced following bacterial infection of mouse and human osteoblasts. Infect. Immun. 71, 1209-1216. doi: 10.1128/IAI.71.3.1209-1216.2003

Shi, S. F., Zhang, X. L., Zhu, C., Chen, D. S., and Guo, Y. Y. (2013). Ultrasonically enhanced rifampin activity against internalized Staphylococcus aureus. Exp. Ther. Med. 5, 257-262. doi: 10.3892/etm.2012.758

Somayaji, S. N., Huet, Y. M., Gruber, H. E., and Hudson, M. C. (2010). UV-killed Staphylococcus aureus enhances adhesion and differentiation of osteoblasts on bone-associated biomaterials. J. Biomed. Mater. Res. Part A 95, 574-579. doi: 10.1002/jbm.a. 32890

Somayaji, S. N., Ritchie, S., Sahraei, M., Marriott, I., and Hudson, M. C. (2008). Staphylococcus aureus induces expression of receptor activator of NF-kappaB ligand and prostaglandinE2 in infected murine osteoblasts. Infect. Immun. 76, 5120-5126. doi: 10.1128/IAI.00228-08

Spellberg, B., and Lipsky, B. A. (2012). Systemic antibiotic therapy for chronic osteomyelitis in adults. Clin. Infect. Dis. 54, 393-407. doi: 10.1093/cid/cir842

Svensson, D., Westman, J., Wickström, C., Jönsson, D., Herwald, H., and Nilsson, B. O. (2015). Human endogenous peptide p33 inhibits detrimental effects of LL-37 on osteoblast viability. J. Periodont. Res. 50, 80-88. doi: 10.1111/jre.12184

Takayanagi, H. (2007). Osteoimmunology: shared mechanisms and crosstalk between the immune and bone systems. Nat. Rev. Immunol. 7, 292-304. doi: $10.1038 /$ nri2062

Takayanagi, H. (2015). Osteoimmunology in 2014: two-faced immunologyfrom osteogenesis to bone resorption. Nat. Rev. Rheumatol. 11, 74-76. doi: 10.1038/nrrheum.2014.219

Testoni, F., Montanaro, L., Poggi, A., Visai, L., Campoccia, D., and Arciola, C. R. (2011). Internalization by osteoblasts of two Staphylococcus aureus clinical isolates differing in their adhesin gene pattern. Int. J. Artif. Organs 34, 789-798. doi: $10.5301 /$ ijao. 5000058

Trouillet-Assant, S., Gallet, M., Nauroy, P., Rasigade, J. P., Flammier, S., Parroche, P., et al. (2015). Dual impact of live Staphylococcus aureus on the osteoclast lineage, leading to increased bone resorption. J. Infect. Dis. 211, 571-581. doi: 10.1093/infdis/jiu386

Tuchscherr, L., Bischoff, M., Lattar, S. M., Noto Llana, M., Pförtner, H., Niemann, S., et al. (2015). Sigma factor SigB Is crucial to mediate Staphylococcus aureus adaptation during chronic infections. PLoS Pathog. 11:e1004870. doi: 10.1371/journal.ppat.1004870

Tuchscherr, L., and Löffler, B. (2015). Staphylococcus aureus dynamically adapts global regulators and virulence factor expression in the course from acute to chronic infection. Curr. Genet. doi: 10.1007/s00294-015-0503-0. [Epub ahead of print].

Tuchscherr, L., Medina, E., Hussain, M., Völker, W., Heitmann, V., Niemann, S., et al. (2011). Staphylococcus aureus phenotype switching: an effective bacterial strategy to escape host immune response and establish a chronic infection. EMBO Mol. Med. 3, 129-141. doi: 10.1002/emmm.201000115

Tucker, K. A., Reilly, S. S., Leslie, C. S., and Hudson, M. C. (2000). Intracellular Staphylococcus aureus induces apoptosis in mouse osteoblasts. FEMS Microbiol. Lett. 186, 151-56. doi: 10.1111/j.1574-6968.2000.tb09096.x

Tung, H., Guss, B., Hellman, U., Persson, L., Rubin, K., and Rydén, C. (2000). A bone sialoprotein-binding protein from Staphylococcus aureus: a member of the staphylococcal sdr family. Biochem. J. 345(Pt 3), 611-619. doi: 10.1042/ bj3450611

Turner, M. D., Nedjai, B., Hurst, T., and Pennington, D. J. (2014). Cytokines and chemokines: at the crossroads of cell signalling and inflammatory 
disease. Biochim. Biophys. Acta 1843, 2563-2582. doi: 10.1016/j.bbamcr.2014. 05.014

Valour, F., Rasigade, J. P., Trouillet-Assant, S., Gagnaire, J., Bouaziz, A., Karsenty, J., et al. (2015b). Delta-toxin production deficiency in Staphylococcus aureus: a diagnostic marker of bone and joint infection chronicity linked with osteoblast invasion and biofilm formation. Clin. Microbiol. Infect. 21, 568.e1-568.e11. doi: 10.1016/j.cmi.2015.01.026

Valour, F., Trouillet-Assant, S., Riffard, N., Tasse, J., Flammier, S., Rasigade, J. P., et al. (2015a). Antimicrobial activity against intra-osteoblastic Staphylococcus aureus. Antimicrob. Agents Chem. 59, 2029-2036. doi: 10.1128/AAC.04359-14t

Vandenesch, F., Lina, G., and Henry, T. (2012). Staphylococcus aureus hemolysins, bi-component leukocidins, and cytolytic peptides: a redundant arsenal of membrane-damaging virulence factors? Front. Cell. Infect. Microbiol. 2:12. doi: $10.3389 /$ fcimb. 2012.00012

Varoga, D., Tohidnezhad, M., Paulsen, F., Wruck, C. J., Brandenburg, L., Mentlein, R., et al. (2008). The role of human beta-defensin-2 in bone. J. Anat. 213, 749-757. doi: 10.1111/j.1469-7580.2008.00992.x

Varoga, D., Wruck, C. J., Tohidnezhad, M., Brandenburg, L., Paulsen, F., Mentlein, R., et al. (2009). Osteoblasts participate in the innate immunity of the bone by producing human beta defensin-3. Histochem. Cell Biol. 131, 207-218. doi: 10.1007/s00418-008-0522-8

Vazquez, V., Liang, X., Horndahl, J. K., Ganesh, V. K., Smeds, E., Foster, T. J., et al. (2011). Fibrinogen is a ligand for the Staphylococcus aureus microbial surface components recognizing adhesive matrix molecules (MSCRAMM) bone sialoprotein-binding protein (bbp). J. Biol. Chem. 286, 29797-29805. doi: 10.1074/jbc.M110.214981

Widaa, A., Claro, T., Foster, T. J., O'Brien, F. J., and Kerrigan, S. W. (2012). Staphylococcus aureus protein a plays a critical role in mediating bone destruction and bone loss in osteomyelitis. PLOS ONE 7:e40586. doi: 10.1371/journal.pone.0040586

Wolf, A. J., Arruda, A., Reyes, C. N., Kaplan, A. T., Shimada, T., Shimada, K., et al. (2011). Phagosomal degradation increases TLR access to bacterial ligands and enhances macrophage sensitivity to bacteria. J. Immunol. 187, 6002-6010. doi: 10.4049/jimmunol.1100232

Wright, K. M., and Friedland, J. S. (2002). Differential regulation of chemokine secretion in tuberculous and staphylococcal osteomyelitis. J. Bone Miner. Res. 17, 1680-1690. doi: 10.1359/jbmr.2002.17.9.1680
Wright, K. M., and Friedland, J. S. (2004). Regulation of chemokine gene expression and secretion in Staphylococcus aureus-infected osteoblasts. Microbes Infect. 6, 844-852. doi: 10.1016/j.micinf.2004.04.008

Yoshii, T., Magara, S., Miyai, D., Nishimura, H., Kuroki, E., Furudoi, S., et al. (2002). Local levels of interleukin-1beta, $-4,-6$ and tumor necrosis factor alpha in an experimental model of murine osteomyelitis due to Staphylococcus aureus. Cytokine 19, 59-65. doi: 10.1006/cyto.2002.1039

Young, A. B., Cooley, I. D., Chauhan, V. S., and Marriott, I. (2011). Causative agents of osteomyelitis induce death domain-containing TNFrelated apoptosis-inducing ligand receptor expression on osteoblasts. Bone 48, 857-863. doi: 10.1016/j.bone.2010.11.015

Zapotoczna, M., Jevnikar, Z., Miajlovic, H., Kos, J., and Foster, T. J. (2013). Iron-regulated surface determinant b (isdb) promotes Staphylococcus aureus adherence to and internalization by non-phagocytic human cells. Cell. Microbiol. 15, 1026-1041. doi: 10.1111/cmi.12097

Zhu, C., Qin, H., Cheng, T., Tan, H. L., Guo, Y. Y., Shi, S. F., et al. (2013). Staphylococcus aureus supernatant induces the release of mouse $\beta$-defensin-14 from osteoblasts via the $\mathrm{p} 38 \mathrm{MAPK}$ and NF-кB pathways. Int. J. Mol. Med. 31, 1484-1494. doi: 10.3892/ijmm.2013.1346

Zhu, C., Wang, J., Cheng, T., Li, Q., Shen, H., Qin, H., et al. (2014). The potential role of increasing the release of mouse $\beta$ - defensin-14 in the treatment of osteomyelitis in mice: a primary study. PLOS ONE 9:e86874. doi: 10.1371/journal.pone.0086874

Zou, W., Amcheslavsky, A., and Bar-Shavit, Z. (2003). CpG oligodeoxynucleotides modulate the osteoclastogenic activity of osteoblasts via toll-like receptor 9 . J. Biol. Chem. 278, 16732-16740. doi: 10.1074/jbc.M212473200

Conflict of Interest Statement: The authors declare that the research was conducted in the absence of any commercial or financial relationships that could be construed as a potential conflict of interest.

Copyright (c) 2015 Josse, Velard and Gangloff. This is an open-access article distributed under the terms of the Creative Commons Attribution License (CC BY). The use, distribution or reproduction in other forums is permitted, provided the original author(s) or licensor are credited and that the original publication in this journal is cited, in accordance with accepted academic practice. No use, distribution or reproduction is permitted which does not comply with these terms. 